\title{
Hydrogen Production by Fluidized Bed Reactors: A Quantitative Perspective Using the Supervised Machine Learning Approach
}

\author{
Zheng Lian ${ }^{1}$, Yixiao Wang ${ }^{1}$, Xiyue Zhang ${ }^{1}$, Abubakar Yusuf ${ }^{1}$, Lord Famiyeh $^{1}$, David Murindababisha ${ }^{1}$, \\ Huan Jin ${ }^{2, *}$, Yiyang Liu ${ }^{3}$, Jun He ${ }^{1, *} \mathbb{C}$, Yunshan Wang ${ }^{4}$, Gang Yang ${ }^{4}$ and Yong Sun ${ }^{1,5, * \mathbb{C}}$ \\ 1 Key Laboratory of Carbonaceous Wastes Processing and Process Intensification of Zhejiang Province, \\ University of Nottingham Ningbo, Ningbo 315100, China; lianzhengsmart@gmail.com (Z.L.); \\ shyyw12@nottingham.edu.cn (Y.W.); ssyxz4@nottingham.edu.cn (X.Z.); aiymashi@gmail.com (A.Y.); \\ Lord.Famiyeh@nottingham.edu.cn (L.F.); DAVID.MURINDABABISHA@nottingham.edu.cn (D.M.) \\ 2 School of Computer Science, University of Nottingham Ningbo, Ningbo 315100, China \\ 3 Department of Chemistry, University College London (UCL), 20 Gordon Street, London WC1H 0AJ, UK; \\ yiyangliu0904@163.com \\ 4 National Engineering Laboratory of Cleaner Hydrometallurgical Production Technology, Institute of Process \\ Engineering, Chinese Academy of Sciences, Beijing 100190, China; wangys@ipe.ac.cn (Y.W.); \\ yanggang@ipe.ac.cn (G.Y.) \\ 5 School of Engineering, Edith Cowan University, 270 Joondalup Drive, Joondalup, WA 6027, Australia \\ * Correspondence: huan.jin@nottingham.edu.cn (H.J.); jun.he@nottingham.edu.cn (J.H.); \\ yong.sun@nottingham.edu.cn (Y.S.)
}

Citation: Lian, Z.; Wang, Y.; Zhang, X.; Yusuf, A.; Famiyeh, L.; Murindababisha, D.; Jin, H.; Liu, Y.; He, J.; Wang, Y.; et al. Hydrogen Production by Fluidized Bed

Reactors: A Quantitative Perspective Using the Supervised Machine Learning Approach. J 2021, 4, 266-287. https://doi.org/10.3390/ j4030022

Academic Editors: Said Elnashaie, Hatem Harraz and Arian Ebneyamini

Received: 16 June 2021

Accepted: 2 July 2021

Published: 7 July 2021

Publisher's Note: MDPI stays neutral with regard to jurisdictional claims in published maps and institutional affiliations.

Copyright: (c) 2021 by the authors Licensee MDPI, Basel, Switzerland. This article is an open access article distributed under the terms and conditions of the Creative Commons Attribution (CC BY) license (https:// creativecommons.org/licenses/by/ $4.0 /)$.
Abstract: The current hydrogen generation technologies, especially biomass gasification using fluidized bed reactors (FBRs), were rigorously reviewed. There are involute operational parameters in a fluidized bed gasifier that determine the anticipated outcomes for hydrogen production purposes. However, limited reviews are present that link these parametric conditions with the corresponding performances based on experimental data collection. Using the constructed artificial neural networks (ANNs) as the supervised machine learning algorithm for data training, the operational parameters from 52 literature reports were utilized to perform both the qualitative and quantitative assessments of the performance, such as the hydrogen yield (HY), hydrogen content (HC) and carbon conversion efficiency (CCE). Seven types of operational parameters, including the steam-to-biomass ratio (SBR), equivalent ratio (ER), temperature, particle size of the feedstock, residence time, lower heating value (LHV) and carbon content (CC), were closely investigated. Six binary parameters have been identified to be statistically significant to the performance parameters (hydrogen yield (HY)), hydrogen content (HC) and carbon conversion efficiency (CCE) by analysis of variance (ANOVA). The optimal operational conditions derived from the machine leaning were recommended according to the needs of the outcomes. This review may provide helpful insights for researchers to comprehensively consider the operational conditions in order to achieve high hydrogen production using fluidized bed reactors during biomass gasification.

Keywords: hydrogen; fluidized bed reactor; supervised machine learning; review

\section{Introduction}

The United Nations (UN) has promoted climate neutrality to produce no net greenhouse gas (GHG) emissions for years, as GHG emission has been considered one of the major causes of global warming [1]. GHG emissions in the atmosphere from fossil fuels, generated either by power plants or automobiles, have also risen and become a tremendous threat to environmental sustainability [2,3]. In recent years, a series of efforts shas been made, including using renewable resources or clean energy such as hydrogen fuels to mitigate the situation, reducing carbon dioxide emissions and in realizing sustainable 
development [4-7]. However, the conventional generation techniques of hydrogen are adopted from fossil fuels, including steam methane reforming (SMR) and derivations from natural gas, also known as "gray hydrogen" [8]. On a related note, hydrogen production using renewable resources is called "blue hydrogen" or biohydrogen (such as by the means of electrolysis, nuclear, solar photovoltaic-PV, wind, hydro or geothermal technologies), which is regarded as more environmentally friendly [3,5,6,9-13]. The current hydrogen generation technologies from different feedstocks are summarized in Figure 1. Apparently, the balance of feedstock between deploying fossil fuel and renewable resources for hydrogen generation has become lopsided, and this trend will become more prominent in the foreseeable future.

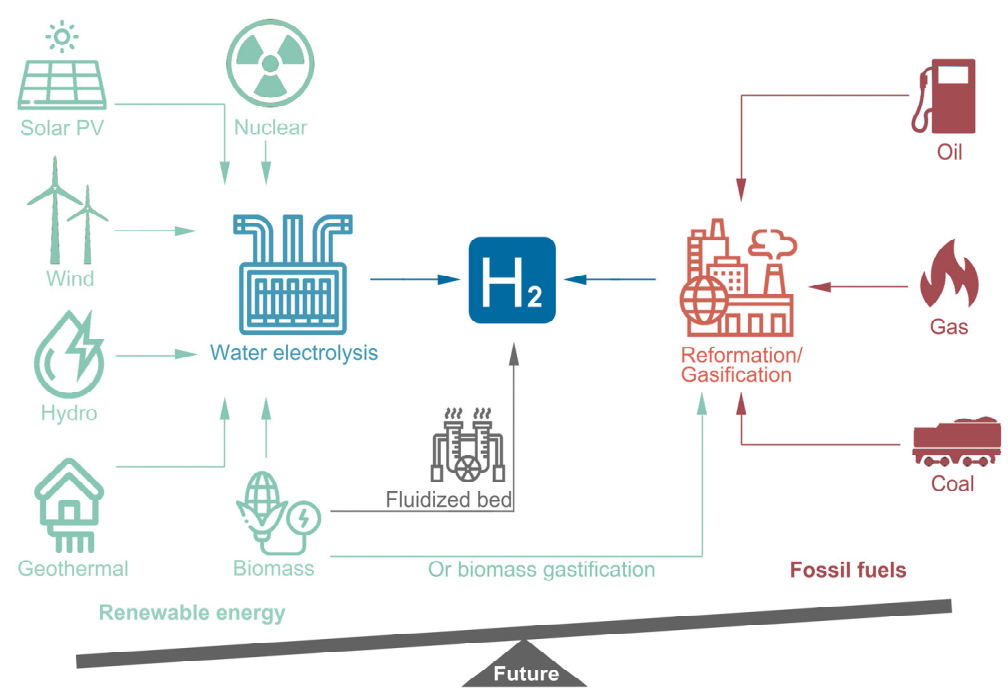

Figure 1. Hydrogen production from different resources via different technical routes. Left: blue hydrogen. Right: gray hydrogen.

While a large number of techniques are available for hydrogen generation, the employment of those techniques faces great challenges when it comes to considering the more complex factors (e.g., cost-effectiveness, reliability and efficiency). For example, electrolysis is considered to be not cost-effective, and bioprocessing through dark fermentation using biomass as the feedstock is not efficient due to its intrinsic, slow biological processing feature [14]. Recently, biomass gasification by fluidized bed reactors (FBRs) has been found to significantly enhance the efficiency of hydrogen production, but its obvious drawbacks, such as complex reaction mechanisms and catalyst usage, somehow limit its application $[15,16]$. For fluidized bed operation, many operational parameters (such as the carbon content, residence time, lower heating values and particle size) play vital roles in determining the expected outcomes (e.g., conversions and yield) [17], and there are very few examples in the literature that try to systematically correlate these critical operational parameters with the corresponding performances. Therefore, this initiates our interest in using our developed artificial neural networks, coupled with a response surface methodology (ANNs-RSM) algorithm, to assess the statistical significance of the investigated operational parameters upon the performances of FBRs during hydrogen generation. The quantitative assessment of reported references for hydrogen generation from different FBRs, to the best of our knowledge, has not been reported before.

\section{Analysis Approach}

\subsection{Literature Collections and Scoping}

In this review, the literature utilized was primarily collected through keyword searches in scientific data bases including Science Direct, Web of Science and Google Scholar. The keyword combinations used in the academic search tool were primarily set as "fluidized bed", "hydrogen production" and "biomass gasification". To keep up with the most recent 
research in this field, selected literature were restricted within the last five years, from 2016 to 2021, in five main subject areas (energy, chemical engineering, chemistry, material science and environmental sciences). As shown in Figure 2, besides 2018, the total number of publications in hydrogen generation from FBRs experienced a steady increase from 2016 to 2020. Among the subject areas, energy (En) related research accounts for up to $40 \%$ of the total publications each year, indicating great research potential and applications in the field. Chemical engineering (CE) contributes around $20 \%$ of the total publications, while other areas individually account for about $10 \%$. The total number of publications in the last three years (2019-2021) also experience a steady increase, indicating an increased research interest in this field.

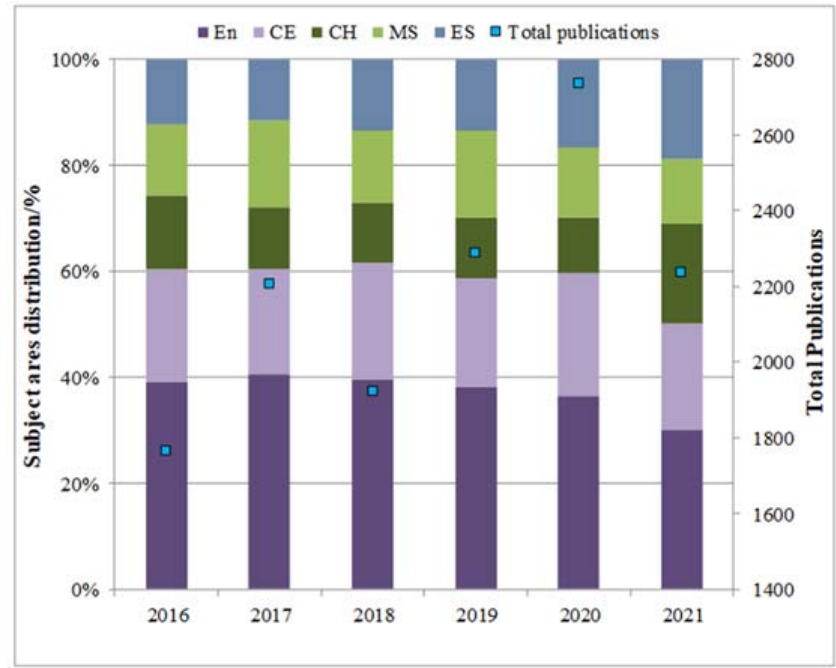

Figure 2. Summary of publication from Scopus for hydrogen generation by subject areas, where En refers to energy, $\mathrm{CE}$ refers to chemical engineering, $\mathrm{CH}$ refers to chemistry, MS refers to material science, and ES refers to environmental sciences.

\subsection{Methodology for Data Training and Predictions}

Artificial neural network (ANN) is a well-developed soft computing technique. Inspired by the human neurological system, ANN is constructed in layers, and information is fed forward to these layers. The configuration of the networks adopts $10 \times 10$ nodes (two hidden layers) feed forward progression using Gaussian as the transformation function, which is often widely adopted as a supervised machine learning configuration setup [18]. In this work, 52 collected references with seven inputs (namely temperature, residence time, equivalent ratio, steam-to-biomass ratio, carbon content, lower heating value, and particle size) and three outputs (hydrogen yield, hydrogen content, and carbon conversion efficiency) were used as a training data set. The cross-out validation technique was deployed, and the mean square error (MSE) and mean absolute relative residuals (MARR) were computed as:

$$
\begin{gathered}
\text { MSE } \%=\frac{1}{N_{\text {sam }}} \sum_{j=1}^{N_{\text {sam }}}\left(r \mid i^{\text {sam }}-r_{i}^{\text {cal }}\right)^{2} \times 100 \% \\
\text { MARR } \%=\frac{1}{N_{\text {sam }}} \sum_{j=1}^{N_{\text {exp }}}\left(\frac{\left|r_{i}^{\text {sam }}-r_{i}^{\text {cal }}\right|}{r_{i}^{\text {sam }}}\right) \times 100 \%
\end{gathered}
$$

where $N_{\text {sam }}$ refers to the number of data set, and $i^{\text {sam }}$ and $r_{i}^{\text {cal }}$ are actual and prediction number, respectively. The acceptable uncertainties are $\pm 10 \%$. The response surface methodology (RSM) was used for data matrix generation, and the corresponding outputs were produced from ANNs via data training. The detailed data handling and algorithm specifica- 
tions can be found from our previously reported works [18-20]. After the completion of the supervised data learning, analysis of variation (ANOVA) using commercial Design Expert ${ }^{\circledR}$ Version 11 software package (Stat-Ease, Inc., Minneapolis, MN, USA) was deployed for statistical analysis.

\section{Source of Hydrogen}

\subsection{Steam Methane Reforming (SMR)}

Currently, approximately $95 \%$ of the world's hydrogen is derived from fossil fuels through such processes as natural gas steam reforming, coal gasification, and petroleum refining. Chemical processing allows the transformation of hydrocarbon fuels to hydrogen under various conditions. The most common pathway to produce hydrogen in the industry is natural gas reforming, also known as steam methane reforming (SMR) [21-23]. This is an endothermic process that applies high-temperature steam to convert methane into carbon dioxide and hydrogen. Methane enters the reactor as feedstock, mixing and reacting with water to form carbon monoxide and hydrogen in the temperature and pressure range of 700 to $1000{ }^{\circ} \mathrm{C}$ and 3-25 bar, respectively, in the presence of a catalyst [24,25]. Meanwhile, the formed carbon monoxide is shifted with steam to produce carbon dioxide and extra hydrogen through a process known as the water-gas shift (WGS) reaction.

$$
\begin{aligned}
& \text { SMR: } \mathrm{CH}_{4}+\mathrm{H}_{2} \mathrm{O} \leftrightarrow \mathrm{CO}+3 \mathrm{H}_{2} ; \Delta \mathrm{H} 298=206 \mathrm{~kJ} \mathrm{~mol}^{-1} \\
& \text { WGS: } \mathrm{CO}+\mathrm{H}_{2} \mathrm{O} \leftrightarrow \mathrm{CO}_{2}+\mathrm{H}_{2} ; \Delta \mathrm{H} 298=-41 \mathrm{~kJ} \mathrm{~mol}^{-1}
\end{aligned}
$$

The overall reaction is expressed as follows:

$$
\mathrm{CH}_{4}+2 \mathrm{H}_{2} \mathrm{O} \leftrightarrow \mathrm{CO}_{2}+4 \mathrm{H}_{2} ; \Delta \mathrm{H} 298=165 \mathrm{~kJ} \mathrm{~mol}^{-1}
$$

Despite achieving the desired conversion, the final products may contain an excessive amount of carbon dioxide, which necessitates further separation, using techniques such as pressure swing adsorption, to purify the hydrogen-rich syngas [24]. On an industrial scale, SMR can achieve the highest hydrogen production efficiency compared to other techniques. Notwithstanding the well-established SMR technology, thermochemical conversion techniques such as auto-thermal reforming, partial oxidation, and plasma catalytic reforming were developed and applied by researchers for efficient hydrogen generation $[23,26-28]$. However, most of the abovementioned thermochemical processes mainly use fossil fuels, generate greenhouse gas emissions, and consume a considerable amount of energy, especially when combined with carbon capture process. The other two important technologies, electrolysis and biomass gasification for hydrogen production, were reviewed in the following section, and a comparison of these three technologies were summarized in Table 1.

\subsection{Electrolysis}

Electrolysis is a hydrogen production approach that dissociates hydrogen from water by applying an induced electric current from an electrolyzer. It is an endothermic reaction, meaning that energy input (electricity) is required during the process. Electrolysis technique is clean, as it only generates hydrogen and oxygen from water molecules without any other harmful emissions $[29,30]$. The overall splitting reaction that occurs in the electrolysis cell, within the electrolyzer, is demonstrated in Equation (6):

$$
2 \mathrm{H}_{2} \mathrm{O} \rightarrow 2 \mathrm{H}_{2}+\mathrm{O}_{2}
$$

Ionic reactions take place at the two electrodes (anode and cathode) within the electrolysis cell, which are connected through electrolytes. At present, the commonly used electrolytes are alkaline, acidic or salt solutions. In an acidic cell, water molecules are primarily converted to oxygen and positively charged protons at the anode. The protons subsequently move forward to the cathode through the electrolyte, whilst electrons are 
transported to the cathode through an external circuit (such as a direct current). Finally, protons and electrons react at the cathode to form hydrogen gas in the presence of a catalyst [31]. This process can be described by the following equations:

$$
\begin{gathered}
\text { Anode reaction: } 2 \mathrm{H}_{2} \mathrm{O} \rightarrow 4 \mathrm{H}^{+}+\mathrm{O}_{2}+4 \mathrm{e}^{-} \\
\text {Cathode reaction: } 2 \mathrm{H}^{+}+2 \mathrm{e}^{-} \rightarrow \mathrm{H}_{2}
\end{gathered}
$$

In the case of an alkaline electrolyte, the electric potential drives the negative hydroxide ions toward the anode and the positive protons to the cathode to form hydrogen gas, as shown below [32]:

$$
\begin{aligned}
& \text { Anode reaction: } 4 \mathrm{OH}^{-} \rightarrow 2 \mathrm{H}_{2} \mathrm{O}+\mathrm{O}_{2}+4 \mathrm{e}^{-} \\
& \text {Cathode reaction: } 2 \mathrm{H}_{2} \mathrm{O}+2 \mathrm{e}^{-} \rightarrow \mathrm{H}_{2}+2 \mathrm{OH}^{-}
\end{aligned}
$$

Among the three electrolytic media, the alkaline electrolyte is more desirable considering potential corrosion or spoilage of some metal electrodes in acidic electrolyte, as well as the possible undesired by-product generation in a salt solution. Recent studies explored many other harsh challenges such as high working temperature and molten hydroxides, the optimized working conditions and the reaction mechanism, to fill the gaps in reference electrodes for hydrogen production under high temperature electrolyte conditions $[33,34]$. Apart from the conventional options, novel alternatives such as proton exchange membrane (PEM) electrolyzer technology, alkaline anion exchange membrane (AAEM), and solid oxide water electrolysis (SOWE), etc., are well-developed [35-38]. Unfortunately, their excessive cost could hinder their large-scale application in hydrogen production, especially, the use of precious metal catalysts including iridium, ruthenium, palladium and platinum during PEM electrolysis [39]. Apart from that, costly electrode materials and high energy consumption also impede the widely application of water electrolysis in large commercial plants. On the other hand, although electrolysis is regarded as a clean process, it could be indirectly associated with carbon emissions if the electricity input is sourced from fossil fuels combustion, unless the "green" electricity comes from renewable sources such as wind or solar energy [40]. Overall, electrolysis can be a promising method for clean hydrogen production, but it has not yet been recognized as cost-effective and widely deployed compared to fossil fuels. Its future development should be focused on the exploitation of inexpensive catalysts and materials, higher productivity, and usage of

\begin{tabular}{|c|c|c|c|c|c|c|c|}
\hline $\begin{array}{l}\text { Production } \\
\text { Technology }\end{array}$ & Feedstock & Processes Involved & $\begin{array}{c}\text { Overall } \\
\text { Reactions }\end{array}$ & Efficiency & Advantages & Limitations & References \\
\hline $\begin{array}{l}\text { Steam } \\
\text { Methane } \\
\text { Reforming }\end{array}$ & $\begin{array}{l}\text { Methane and } \\
\text { steam }\end{array}$ & 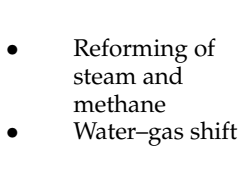 & $\begin{array}{l}\mathrm{CH}_{4}+2 \mathrm{H}_{2} \mathrm{O} \leftrightarrow \\
\mathrm{CO}_{2}+4 \mathrm{H}_{2}\end{array}$ & $70-85 \%$ & $\begin{array}{l}\text { Mature commercially } \\
\text { available technology } \\
\text { Highest hydrogen } \\
\text { production efficiency }\end{array}$ & $\begin{array}{l}\text { - Use of fossil fuels } \\
\text { or refinery } \\
\text { byproducts cause } \\
\text { GHG emission } \\
\text { Additional heat } \\
\text { transfer units }\end{array}$ & [21-25] \\
\hline Electrolysis & $\begin{array}{l}\text { Water and } \\
\text { electricity }\end{array}$ & - Ionic reactions & $\begin{array}{l}2 \mathrm{H}_{2} \mathrm{O} \rightarrow 2 \mathrm{H}_{2}+ \\
\mathrm{O}_{2} ; 2 \mathrm{H}_{2} \mathrm{O} \rightarrow 4 \mathrm{H}^{+} \\
+\mathrm{O}_{2}+4 \mathrm{e}^{-} ; 2 \mathrm{H}^{+} \\
+2 \mathrm{e}^{-} \rightarrow \mathrm{H}_{2}{ }^{*}\end{array}$ & $50-70 \%$ & $\begin{array}{l}\text { - Abundant water and } \\
\text { electricity sources } \\
\text { No GHG emission } \\
\text { and other by-products } \\
\text { unless fossil fuels used } \\
\text { as electricity source }\end{array}$ & $\begin{array}{l}\text { Expensive } \\
\text { catalyst and } \\
\text { materials } \\
\text { Corrosion of } \\
\text { electrodes }\end{array}$ & {$[29-32,35]$} \\
\hline $\begin{array}{l}\text { Biomass } \\
\text { gasification }\end{array}$ & Biomass & $\begin{array}{ll}\text { - } & \text { Pyrolysis } \\
\text { - Char } \\
\text { gasification, } \\
\text { carbon residues } \\
\text { combustion } \\
\text { Tar cracking or } \\
\text { reforming }\end{array}$ & $\begin{array}{l}\text { Biomass }+ \\
\text { Air/oxygen/steam } \\
\rightarrow \mathrm{H}_{2}+\mathrm{CO}+ \\
\mathrm{CO}_{2}+\left(\mathrm{N}_{2}\right)+ \\
\mathrm{CH}_{4}+\mathrm{Tar}+ \\
\mathrm{Char}+ \\
\text { Hydrocarbons }\end{array}$ & $35-55 \%$ & $\begin{array}{ll}\text { - } & \text { Abundant and } \\
\text { renewable resources } \\
\text { - } \quad \text { Carbon neutral } \\
\text { Cost-effective }\end{array}$ & $\begin{array}{l}\text { Thermodynamic } \\
\text { equilibrium and } \\
\text { other byproducts } \\
\text { Relatively low } \\
\text { efficiency }\end{array}$ & [43-47] \\
\hline
\end{tabular}
larger amounts of affordable and renewable electricity [41,42].

Table 1. Comparisons of hydrogen production technologies by steam methane reforming, electrolysis and biomass gasification.

${ }^{*}$ Here, only acidic electrolyte case is shown as a demonstration. 


\subsection{Gasification of Biomass}

Biomass is an abundant renewable organic resource that incorporates forest residues (such as wood logs, straw), agricultural residues (such as cornstalk, rice husk), municipal wastes (such as sewage slurry), biological residues (such as shells), etc. [48-50]. Recently, there is an ever-increasing attention on bioenergy due to its low cost, versatile applications and carbon neutrality [50]. Biomass can be directly used as combustion fuels or upgraded as a feedstock through a variety of methods including thermal conversions (such as gasification, pyrolysis and torrefaction) [49,51,52], chemical conversions (such as Fischer-Tropsch synthesis which converts biomass-based products into a synthetic lubrication oil and synthetic fuel) [53-56], biological conversions (such as fermentation, composting, anaerobic digestion) [57-59], electrochemical conversions (such as electrocatalytic oxidation), etc. [60]. Among such numerus pathways, biomass gasification, as a matured technology either commercially or pilot scale demonstration, has been intensively explored for converting organic materials to hydrogen and other products.

Gasification is a highly endothermic process that includes a series of reactions such as pyrolysis, char gasification, carbon residues combustion, and tar cracking or reforming. Biomass gasification implements biomass as feedstock, operating at high temperatures (700 to $1000{ }^{\circ} \mathrm{C}$ ) with an oxidizing agent (air/oxygen/steam) supply to produce hydrogen, carbon monoxide, carbon dioxide, and other products such as char, tar, nitrogen, methane, etc. [47]. The produced syngas can be transported to power plants for power and electricity generation or used as a chemical feedstock for processes such as methanol production. A typical air gasification reaction of biomass can be expressed as:

$$
\text { Biomass }+\mathrm{Air} \rightarrow \mathrm{H}_{2}+\mathrm{CO}+\mathrm{CO}_{2}+\mathrm{N}_{2}+\mathrm{CH}_{4}+\mathrm{Tar}+\text { Char }+ \text { Hydrocarbons }
$$

Due to the non-combustible nitrogen content of air and incomplete reaction, the hydrogen production efficiency of the air gasifier is generally lower than oxygen and steam gasifiers. Although the hydrogen content of oxygen gasification is enriched, the use of pure oxygen is commercially uneconomical. The steam gasification is a viable pathway of treating biomass and has the highest conversion efficiency of the three oxidizing agents, which is around 53 to $55 \mathrm{vol} \%$ of $\mathrm{H}_{2}$ production, whereas that of air gasification is around 8 to $10 \mathrm{vol} \%$ [61]. Additionally, the carbon-to-hydrogen mass ratio can be reduced through water-gas shift reaction, which further increases the hydrogen content and calorific value of the yield gases:

$$
\text { Biomass }+ \text { steam } \rightarrow \mathrm{H}_{2}+\mathrm{CO}+\mathrm{CO}_{2}+\text { tar }+ \text { char }
$$

Water-gas shift reaction converts carbon monoxide to more hydrogen:

$$
\mathrm{CO}+\mathrm{H}_{2} \mathrm{O} \rightarrow \mathrm{H}_{2}+\mathrm{CO}_{2}
$$

Biomass gasification is versatile for adapting various types of biomass in terms of producing hydrogen and syngas. However, the process is limited by thermodynamic equilibrium and undesired products such as tar, coupled with other challenges such as types of gasification reactors, use of catalyst, operating parameters, etc. [44,62]. Typical gasification reactors are classified as entrained flow gasifiers (EFG), fixed bed gasifiers (FXBG) and fluidized bed gasifiers (FBG), as illustrated in Figure 3. In an EFG as shown in Figure 3A, biomass can be fed at the top with the gasifying agent (downflow system) or the bottom through side burners (upflow system). Normally, biomass is heated in a temperature range of 1200 to $2000{ }^{\circ} \mathrm{C}$ at 20 to 70 bar, during which particles travel with oxygen and steam along the reactor in a very short residence time [63]. Since the gas flow velocity in the system is high enough, both the biomass fuels and the formed synthesis gas are entrained in the same flow direction. Meanwhile, the high temperature and pressure can result in almost complete reaction that high quality of synthesis gas can be obtained. Most importantly, the high temperature ensures a full destruction of the undesired volatile 
components such as tar. However, it is challenging that a pre-treatment of the biomass fuel is required to ensure unhindered flow and stable heat and mass transfer during the reaction [63]. The fuels must be dried and milled into finely ground particles with size diameter of hundred micrometers before it can be introduced to the systems. Nevertheless, due to different source and the intrinsic physical properties of biomass, the particle-stated biomass fuels still suffer from poor mobility with flows. This may lead to insufficient mixing, and therefore restrict the overall efficiency. Besides, the operating temperature is beyond the ash fusion temperature and slagging could be a challenging issue in the system. In addition, keeping a high flow demands large oxidant input into the system $[63,64]$.

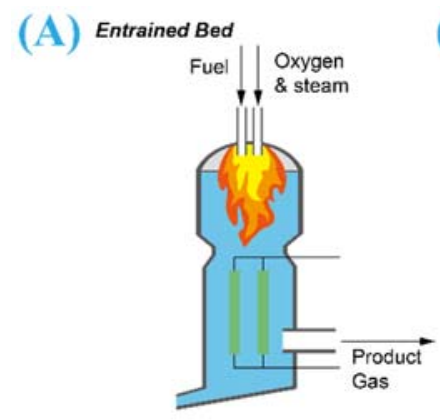

(B) Fixed Bed
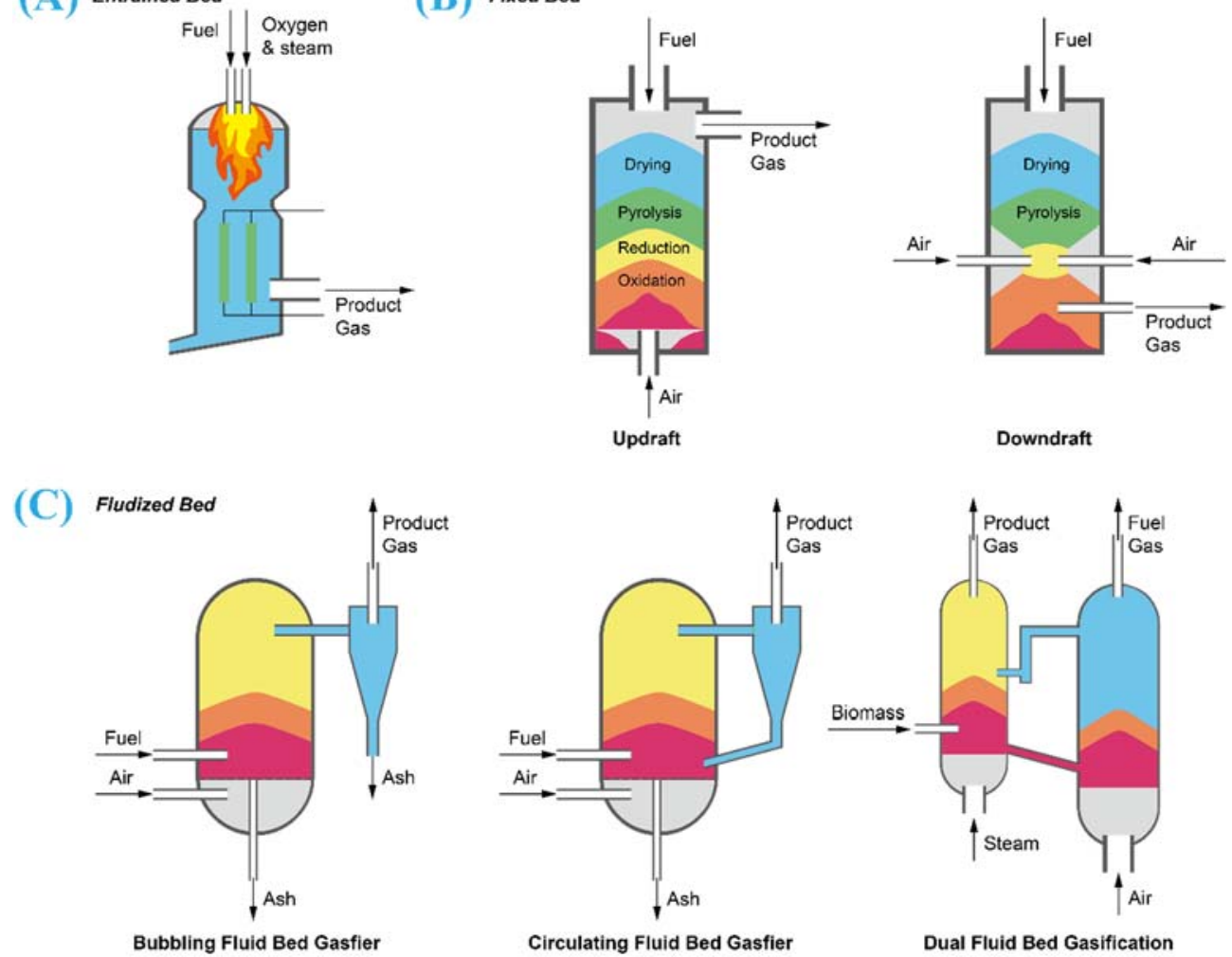

Figure 3. Schematic illustration of different types of gasifiers: (A) entrained flow, (B) fixed bed (left: updraft and right: downdraft) and (C) Fluidized bed (left: bubbling fluidized bed, middle: circulating fluidized bed and right: dual fluidized bed).

Fixed bed gasifier has a bed of solid fuel particles in a cylindrical space, as demonstrated in Figure 3B. FXBGs normally operate in a temperature range of 300 to $1000{ }^{\circ} \mathrm{C}$ without extra pressure exerted to the system. FXBGs are categorized into updraft and downdraft types. In these configurations, the gasification agent enters the reactor in different directions $[45,65]$. In updraft FXBG (see Figure 3B), the biomass fuel is introduced from the top entrance and the gasification agent (steam and oxygen) from the bottom of the reactor. The biomass descends through the bed while being heated and converted to synthesis gas. The gasification process includes drying, pyrolysis, reduction, and oxidation, after which the synthesis gas leaves the gasifier through the top exit. Hydrogen content produced by the updraft FXBG is higher than EFG, but contains higher fractions of tar (10 to $20 \mathrm{~g} / \mathrm{m}^{3}$ ) and a huge amount of other pyrolysis products, which need to be removed before further utilization [65]. For downdraft FXBGs, the reactor through an inlet and the targeted syngas is separated from the bottom, as shown in Figure 3B. The downdraft FXBGs can enable hydrocarbon cracking and depressing tar content [43,45]. However, downdraft FXBGs usually have a lower gas yield than upward FXBGs and are therefore limited to upscaling for commercial production. Overall, although fixed bed gasifiers produce cleaner 
product gas, relative high tar content and low conversion rate severely limit FXBGS to small scale applications $[43,65]$.

Owing to excellent solid-gas contact and promising heat and mass transfer, fluidized bed gasifiers exhibit better performance for biomass gasification than EFGs and FXBGs. FBGs are viable to deal with a variety of types and sizes of biomass and have great potential to scale up for commercial applications [66]. In a fluidized bed, the biomass is introduced above a dense fluid bed (typically quartz sand or catalytic particles) and upward flow of gasification reactants, supplied to the bottom of the gasifier, serve as fluidizing medium. The bed operating temperature is normally within a range of 700 to $1000{ }^{\circ} \mathrm{C}$, which is below the ash fusion or softening point to avoid ash agglomeration and blockage or defluidization of the bed [66,67]. Biomass settles to the hot bed surface and is heated rapidly, enabling drying and pyrolysis to take place. The uniform high temperature profile maintained in FBGs is beneficial for achieving a high carbon conversion efficiency and reduction of tar and light hydrocarbons. Meanwhile, constant fluidization facilitates continuous and proper mixing between the oxidant and biomass particles, promoting a high reaction efficiency. However, char combustion under such temperature partly restricts gasification process and negatively impacts the entire process. In addition, tar formation is the main barrier towards higher yield of synthesis gas [68,69].

Fluidized gasification reactors are operated in three modes including bubbling, circulating, and dual beds, as depicted in Figure 3C. In a bubbling fluidized bed (BFB), the fuel is introduced from the bottom or side of the bed. The bed starts bubbling when the velocity of gasification agent is beyond the minimum fluidization velocity. The product syngas is extracted from the top of the reactor and cleaned in a cyclone, as shown in Figure $3 \mathrm{C}$. BFB demonstrates capability to treat high-moisture biomass, but significant instability in the presence of bubbling and rising gas channeling [70,71]. Circulating fluidized bed (CFB) features two operating units, which are a fast velocity riser reactor and a circulating loop cyclone (Figure $3 \mathrm{C}$ middle). In this concept, biomass is treated under a higher gas velocity (superficial flow velocity) than BFB in a more drastic fluidization state. A mixture of product syngas and bed particles rise to the top and separated in cyclones, where the issued-out solids recirculate into a riser from the bottom. Therefore, greater overall efficiency could be realized through the looping design [46]. Dual fluidized bed (DFB) systems or two-stage fluidized bed systems comprise of two fluidized bed reactors interlinked with a solid looping configuration, as illustrated in Figure $3 C$ (right) [72]. They can be a combination of two BFBs, two CFBs or a BFB and a CFB. The two connected fluidized beds are independently accountable for pyrolysis and combustion reactions [73]. In the combustion chamber, air and fuels are fed in and solid reactants are heated and combusted. Consequently, combustion turns flue gas, at the top of reactor, into a connected cyclone, after which the bed materials are transported to the second FBG. Biomass gasification takes place with the help of a hot bed material and steam to produce syngas gas and char. Later, the bed material and char are transferred back to the first FBG for char combustion, repeating the previous steps. By this means, the two processes do not interfere with each other, and high conversion efficiency is ensured [72,74]. Table 2 summarizes different types of gasifiers for biomass gasification, as well as their operational conditions, advantages and limitations. 
Table 2. Comparison of different types of gasifiers for biomass gasification including their operational conditions, advantages and limitations.

\begin{tabular}{|c|c|c|c|c|c|c|c|}
\hline Gasifier Types & $\begin{array}{c}\text { Design } \\
\text { Configurations }\end{array}$ & Descriptions & $\mathrm{T}\left({ }^{\circ} \mathrm{C}\right)$ & $\mathbf{P}$ (bar) & Advantages & Limitations & References \\
\hline \multirow{2}{*}{ Entrained flow } & Upflow system & $\begin{array}{l}\text { Biomass fed at } \\
\text { the bottom } \\
\text { with the } \\
\text { gasifying agent } \\
\text { Syngas exits } \\
\text { from the top }\end{array}$ & $1000-1400$ & $25-30$ & \multirow{2}{*}{$\begin{array}{ll}\text { - } & \text { High quality of } \\
\text { synthesis gas } \\
\text { Elimination of } \\
\text { tar } \\
\text { - Short residence } \\
\text { time }\end{array}$} & \multirow{2}{*}{$\begin{array}{l}\text { High gas flow } \\
\text { velocity, high } \\
\text { temperature } \\
\text { and pressure, } \\
\text { large oxidant } \\
\text { demand } \\
\text { High energy } \\
\text { consumption } \\
\text { Complex } \\
\text { pretreatment }\end{array}$} & \multirow{2}{*}[63,64]{} \\
\hline & $\begin{array}{l}\text { Downflow } \\
\text { system }\end{array}$ & $\begin{array}{l}\text { Biomass fed at } \\
\text { the top with } \\
\text { the gasifying } \\
\text { agent } \\
\text { Syngas exits } \\
\text { from the } \\
\text { bottom }\end{array}$ & $1200-2000$ & $20-70$ & & & \\
\hline \multirow{2}{*}{ Fixed bed } & Updraft & $\begin{array}{l}\text { Biomass fed at } \\
\text { the top and } \\
\text { gasifying agent } \\
\text { from the } \\
\text { bottom of } \\
\text { reactors } \\
\text { Syngas exits } \\
\text { from the top }\end{array}$ & $300-1000$ & $\begin{array}{l}\text { Atmospheric } \\
\text { pressure }\end{array}$ & $\begin{array}{l}\text { Higher gas } \\
\text { yield }\end{array}$ & $\begin{array}{l}\text { Higher } \\
\text { fractions of tar } \\
\text { and other } \\
\text { byproducts }\end{array}$ & {$[45,65]$} \\
\hline & Downdraft & $\begin{array}{l}\text { Biomass fed at } \\
\text { the top and } \\
\text { gasifying agent } \\
\text { from the } \\
\text { middle of } \\
\text { reactors } \\
\text { Syngas exits } \\
\text { from the } \\
\text { bottom }\end{array}$ & $300-1000$ & $\begin{array}{l}\text { Atmospheric } \\
\text { pressure }\end{array}$ & $\begin{array}{l}\text { Hydrocarbon } \\
\text { cracking and } \\
\text { limited tar } \\
\text { content }\end{array}$ & $\begin{array}{l}\text { Lower gas } \\
\text { yield } \\
\text { tar formation } \\
\text { and other } \\
\text { byproducts }\end{array}$ & {$[43,45]$} \\
\hline \multirow{3}{*}{ Fluidized bed } & Bubbling & $\begin{array}{l}\text { Biomass fed at } \\
\text { the bottom or } \\
\text { side and } \\
\text { gasifying agent } \\
\text { from the } \\
\text { bottom of } \\
\text { reactors } \\
\text { - Syngas exits } \\
\text { from the } \\
\text { bottom }\end{array}$ & 700-1000 & $1-35$ & $\begin{array}{ll}\text { - } & \text { Capable of } \\
\text { treating high } \\
\text { moisture } \\
\text { biomass } \\
\text { - } \quad \text { Uniform high } \\
\text { temperature } \\
\text { profile } \\
\text { - } \quad \text { Betting mixing } \\
\text { High carbon } \\
\text { conversion } \\
\text { efficiency } \\
\text { No ash } \\
\text { agglomeration }\end{array}$ & $\begin{array}{l}\text { Tar formation } \\
\text { and other } \\
\text { byproducts }\end{array}$ & [75-79] \\
\hline & Circulating & $\begin{array}{l}\text { Biomass fed to } \\
\text { the bed and } \\
\text { gasifying agent } \\
\text { from the } \\
\text { bottom of } \\
\text { reactors } \\
\text { Syngas exits } \\
\text { from the top } \\
\text { and partially } \\
\text { recycled from } \\
\text { cyclone and } \\
\text { sent back to } \\
\text { gasifier }\end{array}$ & 700-1000 & $1-20$ & $\begin{array}{ll}\text { - } & \text { Capable of } \\
\text { treating high } \\
\text { moisture } \\
\text { biomass } \\
\text { - } \quad \text { Uniform high } \\
\text { temperature } \\
\text { profile } \\
\text { - } \quad \text { Better mixing } \\
\text { High carbon } \\
\text { conversion } \\
\text { efficiency } \\
\text { No ash } \\
\text { agglomeration }\end{array}$ & $\begin{array}{l}\text { Extra operating } \\
\text { units }\end{array}$ & {$[46,80-83]$} \\
\hline & Dual & $\begin{array}{l}\text { Two operation } \\
\text { units combined } \\
\text { pyrolysis and } \\
\text { combustion }\end{array}$ & 700-1000 & $1-35$ & 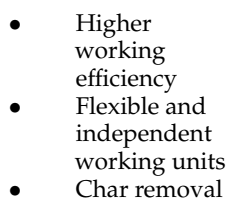 & $\begin{array}{l}\text { - } \quad \begin{array}{l}\text { Higher energy } \\
\text { demand }\end{array} \\
\text { - } \quad \text { Extra operating } \\
\text { units }\end{array}$ & [84-89] \\
\hline
\end{tabular}




\section{Statistical Analysis of Parameter upon Output}

In this review, among the different operational parameters, we choose seven parameters (temperature, residence time, equivalent ratio, steam-to-biomass ratio, carbon content, lower heating value and particle size) due to availability in reported literatures. Taking the feedstock sources for an example, different sources of feedstock may own various calorific values, carbon content, or moisture content that can significantly affect the conversion rate to hydrogen. The results are summarized in Tables 3 and 4 (Table 3 for different types of FBGs and Table 4 for general FBGs that the types were not specified in the literatures). Using the collected references as training data set via ANNs-RSM algorithm, the predictions were made against the actual reported values from references. The results are shown in Figure 4. Apart from some values possessing relative higher uncertainties over $\pm 20 \%$, the majority of calculated data fall into the reasonable range, indicating that our constructed network can generate reliable predictions.

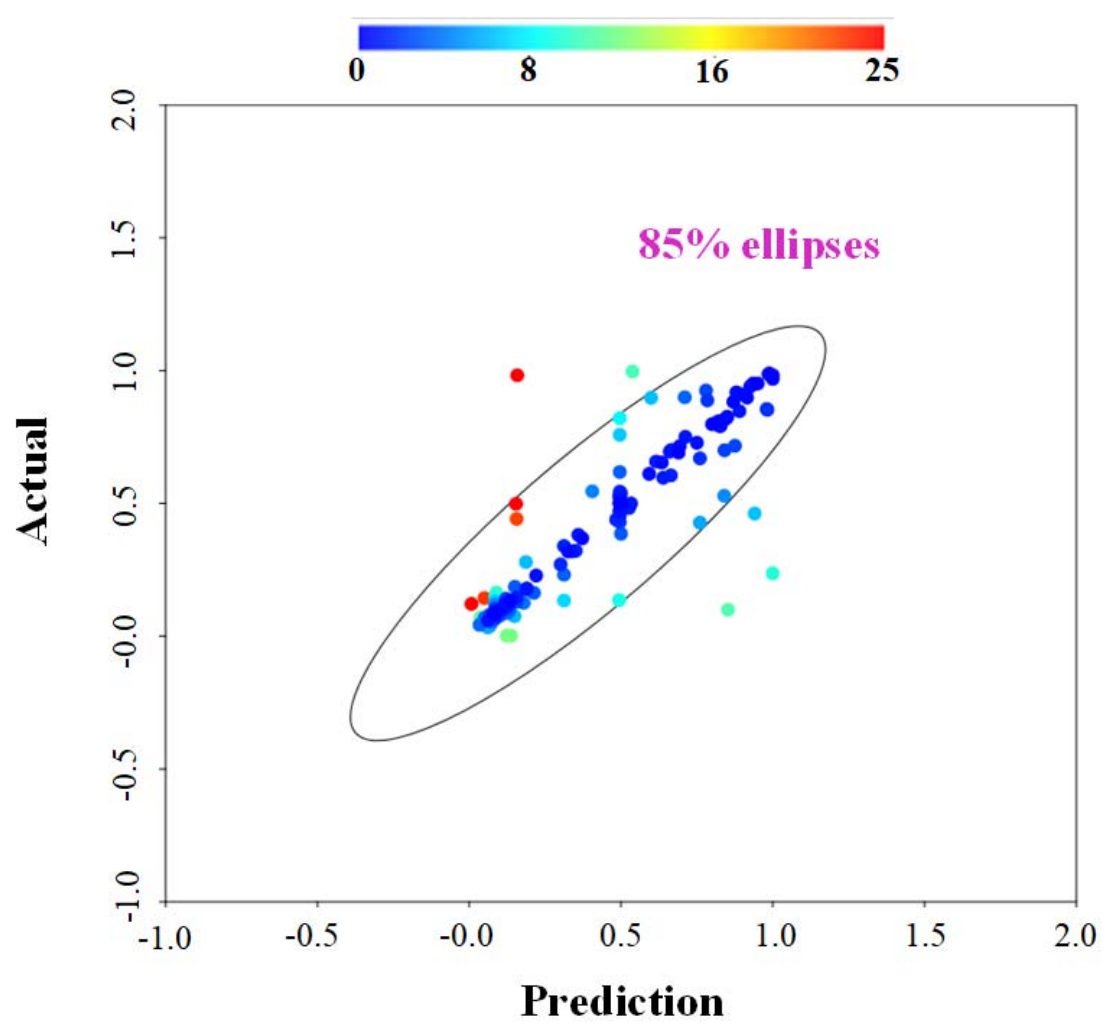

Figure 4. Analysis result-actual versus prediction from ANNs modeling, where color bar represents the uncertainties.

The types of fluidized bed reactors and their corresponding reported hydrogen contents from Tables 3 and 4 were summarized and plotted in Figure 5. Obviously, different types of fluidized bed reactors from different reported sources tend to yield different reported values of hydrogen contents. In Figure 5, the top three reported hydrogen contents were annotated. For example, the hydrogen content could reach nearly $80 \%$ when almond shell was fed into fluidized bed gasifier using commercial nickel as catalyst. The bubbling fluidized bed reactor also generated hydrogen content reaching around 70\% when empty fruit bunch was used as feedstock. 


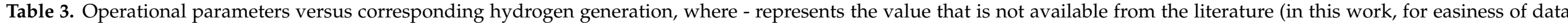
handling, the voids were replaced by the average reported value).

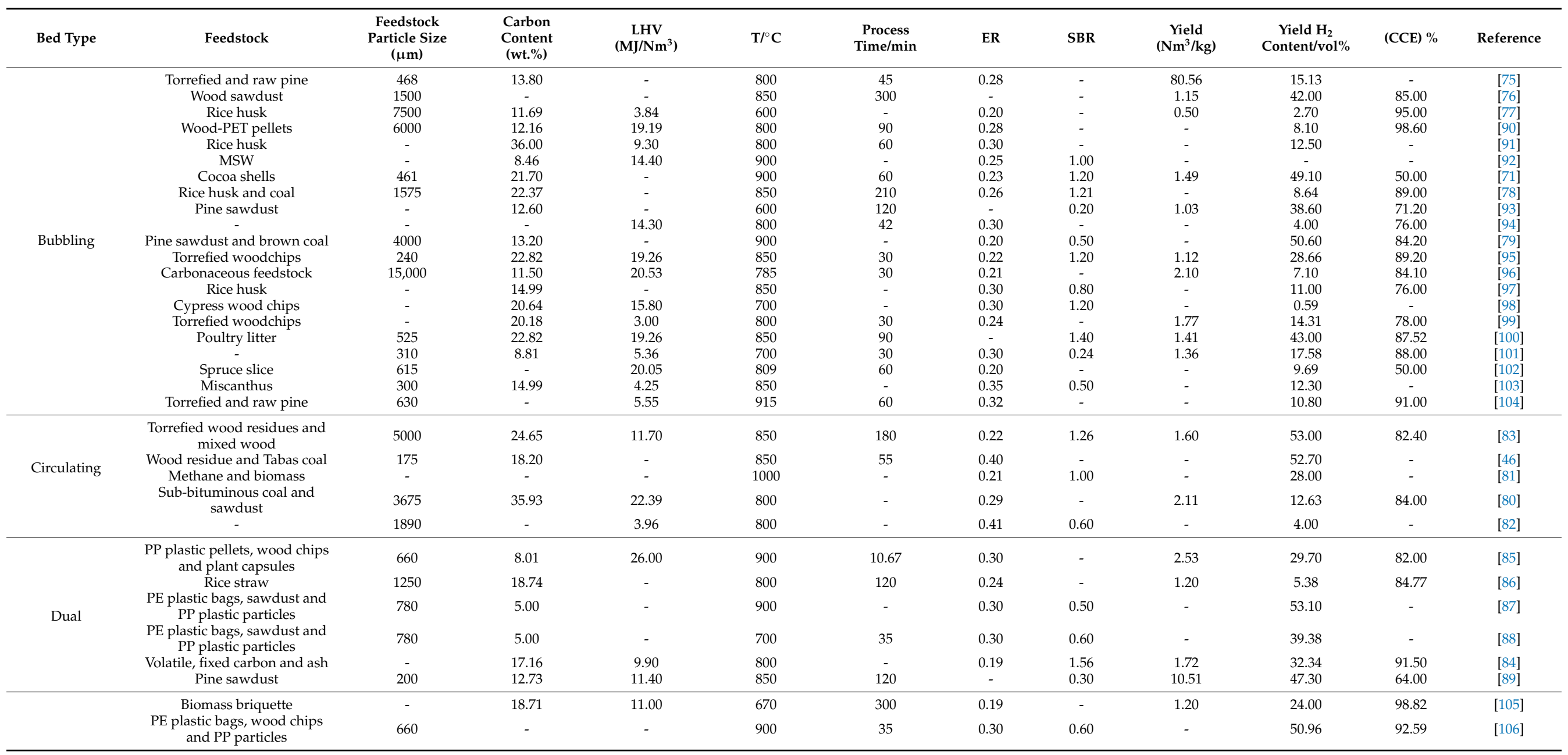




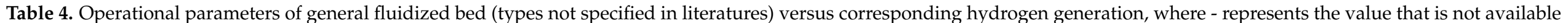
from the literature (in this work, for easiness of data handling, the voids were replaced by the average reported value).

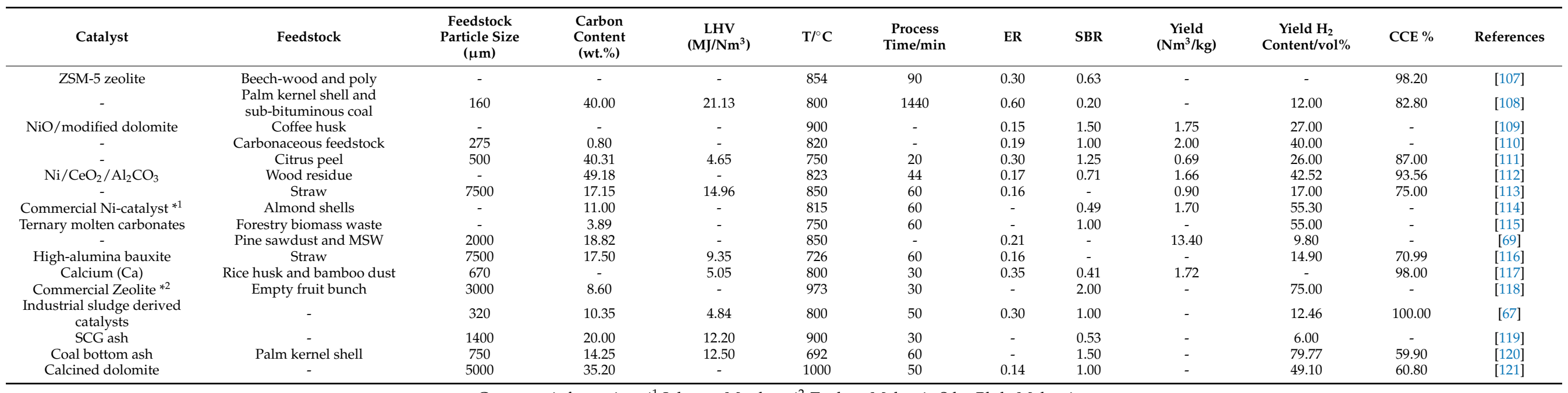




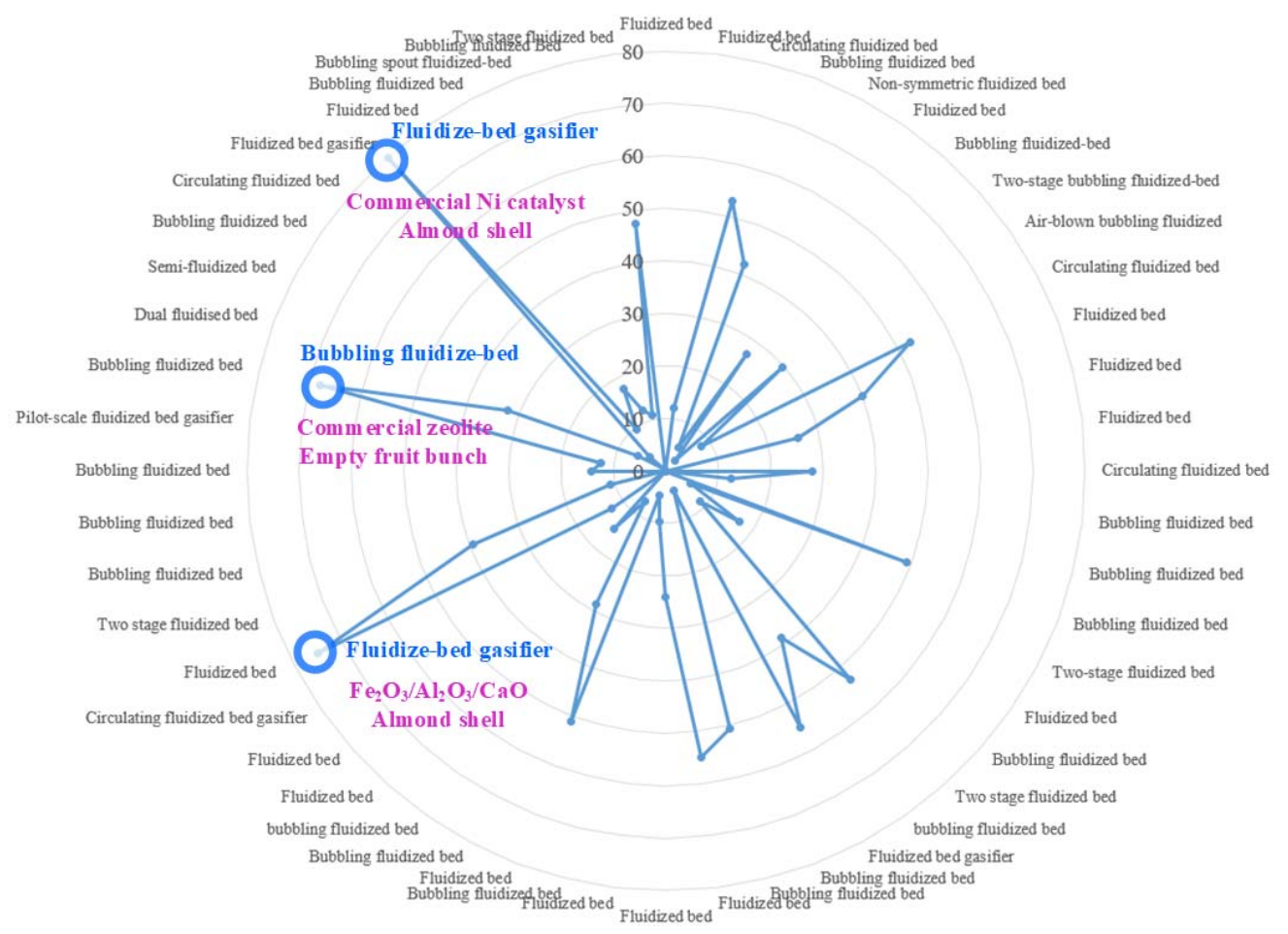

Figure 5. Types of fluidized bed versus hydrogen yield (vol-\%), the circles with number labelled represent hydrogen yield (\%) and the top three hydrogen yield case are displayed in blue and purple.

The statistical analysis of the impact of seven process parameters on the corresponding three outputs using ANOVA are shown in Figure 6. In this work, instead of investigating the statistical significance of singular process parameters upon the responses, we mainly focused on statistical significance of the binary combined parameters upon those three responses, which is often more meaningful from a practical operation point of view. Among all the investigated binary combined parameters (total $7 \times 6=42$ different combinations, see Figure 6A), six binary combined parameters (Figure 6B) were identified and found to be statistically significant to the response.

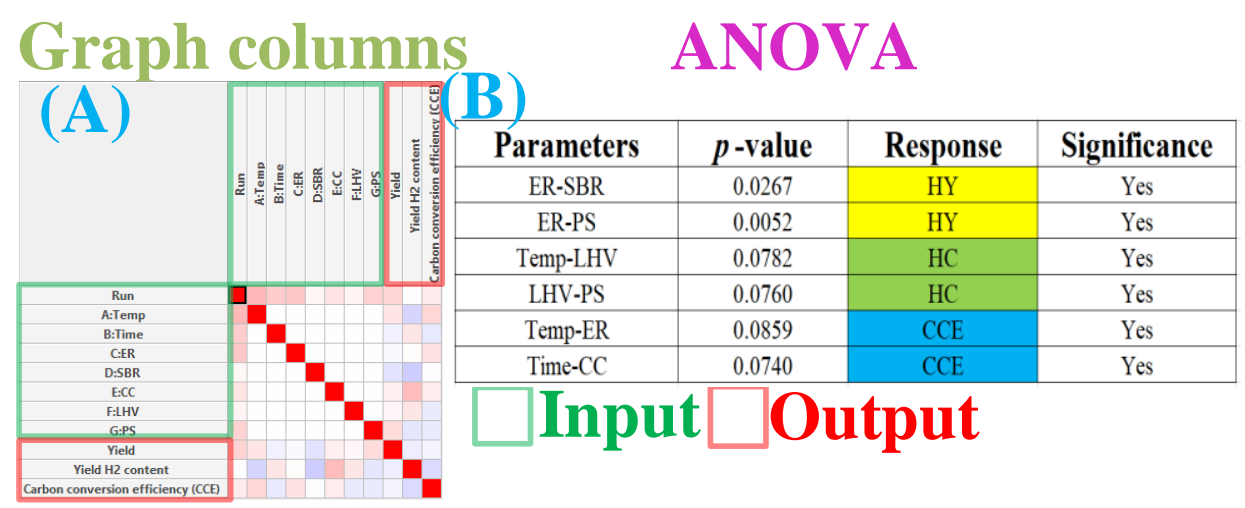

Figure 6. Statistical analysis for the impact of process parameters upon responses, (A) graph column of parameters and responses, (B) ANOVA of all parameters towards the responses, where HY represents hydrogen yield, HC refers to hydrogen content, and CCE refers to carbon conversion efficiency (\%), SBR refers to steam-to-biomass ratio (-), ER refers to equivalence ratio, LHV refers to lower heating value $\left(\mathrm{MJ} / \mathrm{Nm}^{3}\right)$, CC refers to carbon content $(\%)$, PS refers to particle size $(\mu \mathrm{m})$ and Temp refers to temperature $\left({ }^{\circ} \mathrm{C}\right)$. 
The statistical analysis of the impact of the binary combined factors on responses are shown in Figure 7. Figure 7A shows the steam-to-biomass ratio (SBR) and equivalence ratio (ER) versus hydrogen yield (HY). SBR refers to the ratio between steam content and biomass fed to the gasifier, and ER represents the actual air-to-biomass ratio with respect to stoichiometry for complete combustion $[88,113]$. Both SBR and ER are significant parameters that need to be maintained at optimal values in order to achieve relatively high HY. High HY values were found at both high SBR and ER regions in Figure 7A. It can be explained that a higher value of SBR (i.e., 1.5-2.0) tends to increase HY on account of the water-gas shift reactions. Meanwhile, higher ER (above 0.5 ) indicates the availability of more oxidizing agent in the system, which enhances the oxidation reaction. It also maintains continuous tar cracking and eventually boosts the total amount of producer gas, although HY does not experience significant growth [113]. It should be noted that both SBR and ER should not go beyond a limit (mentioned above) because more oxidizing agent in the gasifier would lead to incomplete gasification and an increase in carbon-contained gases, leading to adverse effect on HY. In addition, both high values could result in more energy and material consumption. Interestingly, high HY is also found in the region of lower SBR and ER values. For example, reduction of ER to a range within 0.2 to 0.3 facilitates hydrogen production and other gaseous content. However, low ER below 0.15 (Figure 7A) can leave a proportion of unconverted char and tar in the system. If SBR is too low, a deficiency of the water-gas shift process would likewise restrict the final HY. Figure 7B demonstrates the particle size (PS) and ER against HY. It is suggested that under a low ER, small feedstock particle size (e.g., $3000 \mu \mathrm{m}$ ) enriches HY, as large surface area favors efficient heat transfer during gasification. Conversely, larger sized biomass feedstock suffers from poor thermal decomposition, leading to high volatile content, which in return produces high tar content and low HY [122]. Figure 7C depicts the influence of residence time (Time) and temperature (Temp) on hydrogen content (HC) in the producer gas. Although the results suggested that longer residence time (such as $1500 \mathrm{~min}$ ) also leads to higher $\mathrm{HC}$, it is regarded as inefficient considering factors such as a noticeable amount of energy, material input, and other economic considerations. On the other hand, adequate residence time should be ensured, as both temperature and reactions need certain periods to attain steady state. This corresponds to the predictions in Figure $7 \mathrm{C}$ that the optimal residence time is controlled within $180 \mathrm{~min}$. Conversely, higher temperatures intensify HC values due to the intrinsic endothermic process of hydrogen production and a decrease in carbon monoxide. However, it is also dependent on the moisture content of the feedstock, as part of the energy would be consumed during drying. Therefore, lower temperature may impede effective processing of biomass with high moisture content [123]. Nevertheless, the char combustion demands extra energy input at high temperature conditions, i.e., over $850{ }^{\circ} \mathrm{C}$, where $\mathrm{HC}$ is limited under this circumstance. As for lower heating value (LHV), there is an increasing trend of HC directly associated with larger LHV of biomass fuels, as shown in Figure 7D. This suggests that favor high LHV of the feedstock favors $\mathrm{HC}$ at any instance. Carbon conversion efficiency (CCE) is determined by the mass of carbon in producer gas over the mass of carbon in biomass feedstock. A High CCE value implies high hydrogen to carbon monoxide ratio as well as high tar conversion [124]. The analysis results, as illustrated in Figure 7F, shows the estimated optimal CCE values fall within the ER and temperature range of $0.15<\mathrm{ER}<0.35$ and 700 to $850^{\circ} \mathrm{C}$, respectively. Restricting the residence time within $180 \mathrm{~min}$, a high CCE can be achieved by selecting biomass with a wide range of carbon content (CC) over 8\%, as seen in Figure 7F. Overall, the parametric factors surveyed above have a joint influence on hydrogen production and a rough prediction can be made based on those given values. Therefore, this may serve as a guide for users when considering hydrogen production from biomass using fluidized bed gasifiers. 

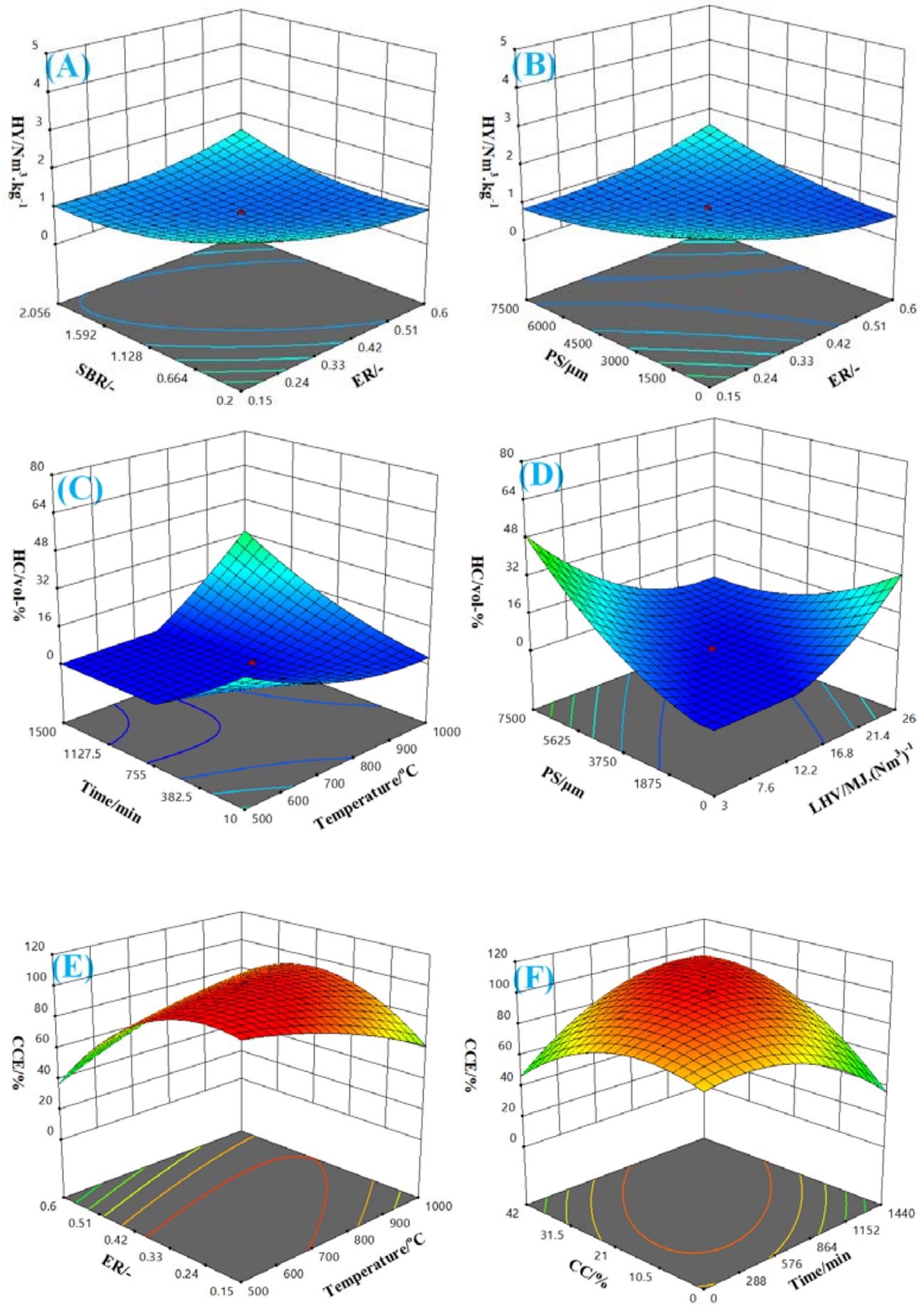

Figure 7. Statistical analysis for the impact of process parameters upon responses, (A) SBR-ER-HY, (B) PS-ER-HY, (C) Time-Temp-HC, (D) PS-LHV-HC, (E) ER-Temp-CCE and (F) CC-Time-CCE.

\section{Conclusions}

In this paper, the commonly used hydrogen production technologies including steam methane reforming, electrolysis, and biomass gasification were reviewed and compared. Among the mentioned technologies, biomass gasification using fluidized bed reactor was thoroughly reviewed, including the types and operating conditions. Biomass gasification can be considered as a promising alternative technology for hydrogen production owing to the renewable, abundant, carbon neutral, and cost-effective nature of the feedstock. Subsequently, biomass gasifiers including entrained flow gasifier, fixed bed and fluidized 
bed reactor (FBR) were compared. Due to the inherent advantage of enhanced mass and heat transfer, the FBR was identified as the most promising biomass gasification technique for hydrogen production. In addition, to quantitatively assess the pivotal operational parameters of FBR, seven key inputs and three outputs were extracted from the reported literatures as a training data set. These inputs are SBR, ER, temperature, PS of feedstock, residence time, LHV, and CC. The three outputs are HY, HC, and CCE. The results of the statistical analysis indicate that six binary parameters are statistically significant to the outputs. In terms of high HY, SBR, and ER, relatively low values were suggested for efficient reaction and economic considerations. A high $\mathrm{HC}$ was proposed based on a shorter reaction time within $180 \mathrm{~min}$ under $850^{\circ} \mathrm{C}$ for biomass that contained high LHV and fine particle sizes. The optimal CCE values could be obtained within an ER range of 0.15 to 0.35 , operating temperature of 700 to $850{ }^{\circ} \mathrm{C}$, reaction time within $180 \mathrm{~min}$, and with CC values beyond $8 \%$, as inputs. This analysis may provide a revealing insight for users who wish to realize high working efficiency using biomass gasification technology for hydrogen production. However, besides the parametric conditions mentioned in the content, other essential factors such as the types and amount of catalyst were not assessed in this paper. This is because currently, the data could not be quantified as an effective data input to the analysis system. Therefore, both the qualitative and quantitative evaluation of this factor will be conducted in our future study.

Author Contributions: Z.L.: drafting, writing and analysis; Y.W. (Yixiao Wang): data curation; X.Z.: data curation; A.Y.: writing; L.F.: writing and drafting; D.M.: writing and drafting; H.J.: programming and supervision; Y.L.: writing and supervision; J.H.: supervision; Y.W. (Yunshan Wang): project management; G.Y.: project management; Y.S.: writing, supervision and project management. All authors have read and agreed to the published version of the manuscript.

Funding: Funding was acquired through the University of Nottingham Ningbo China (FoSE New Researchers Grant I01210100011), the Faculty Inspiration Grant of University of Nottingham (FIG2019), the Qianjiang Talent Scheme (QJD1803014), the National Key R\&D Program of China (Grant: 2018YFC1903500), the Ningbo Science and Technology Innovation 2025 Key Project (Grant 2020Z100) and the Ningbo Municipal Commonweal Key Program (Grant 2019C10033 and 2019C10104).

Institutional Review Board Statement: Not applicable.

Informed Consent Statement: Not applicable.

Data Availability Statement: Not applicable.

Acknowledgments: The authors also sincerely appreciate the critical and insightful comments raised by those anonymous reviewers for significantly improving the quality of this work.

Conflicts of Interest: The authors declare no conflict of interest.

\section{Abbreviations}

AAEM Alkaline anion exchange membrane

ANNs Artificial neural networks

ANNs-RSM Artificial neural networks coupled with response surface methodology

ANOVA Analysis of variation

BFB Bubbling fluidized bed

CC Carbon content

CCE Carbon conversion efficiency

$\mathrm{CE} \quad \mathrm{Chemical}$ engineering

CFB Circulating fluidized bed

$\mathrm{CH} \quad$ Chemistry

DFB Dual fluidized bed

En Energy

ES Environmental sciences

FBG Fluidized bed gasifiers

FBR Fluidized bed reactors 


$\begin{array}{ll}\text { EFG } & \text { Entrained flow gasifiers } \\ \text { ER } & \text { Equivalence ratio } \\ \text { FXBG } & \text { Fixed bed gasifiers } \\ \text { GHG } & \text { Greenhouse gas } \\ \text { HC } & \text { Hydrogen content } \\ \text { HY } & \text { Hydrogen yield } \\ i^{\text {sam }} & \text { Actual } \\ \text { LHV } & \text { Lower heating value } \\ \text { MARR } & \text { Mean absolute relative residuals } \\ \text { MS } & \text { Material science } \\ \text { MSE } & \text { Mean square error } \\ N_{\text {sam }} & \text { Number of data set } \\ \text { PEM } & \text { Proton exchange membrane } \\ \text { PS } & \text { Particle size } \\ r_{i}^{\text {cal }} & \text { Prediction } \\ \text { RSM } & \text { Response surface methodology } \\ \text { SBR } & \text { Steam-to-biomass ratio } \\ \text { SMR } & \text { Steam methane reforming } \\ \text { SOWE } & \text { Solid oxide water electrolysis } \\ \text { Temp } & \text { Temperature } \\ \text { UN } & \text { United Nations } \\ \text { WGS } & \text { Water-gas shift } \\ & \end{array}$

\section{References}

1. Sun, Y.; Lin, Z.; Peng, S.H.; Sage, V.; Sun, Z. A Critical Perspective on CO2 Conversions into Chemicals and Fuels. J. Nanosci. Nanotechnol. 2019, 19, 3097-3109. [CrossRef]

2. Schlapbach, L.; Zuttel, A. Hydrogen-storage materials for mobile applications. Nature 2001, 414, 353-358. [CrossRef]

3. Sun, Y.; Zhang, J.; Yang, G.; Li, Z. Analysis of trace elements in corncob by microwave Digestion-ICP-AES. Spectrosc. Spect. Anal. 2007, 27, 1424-1427.

4. Sun, Y.; He, J.; Yang, G.; Sun, G.; Sage, V. A Review of the Enhancement of Bio-Hydrogen Generation by Chemicals Addition. Catalysts 2019, 9, 353. [CrossRef]

5. Al-Juboori, O.; Sher, F.; Khalid, U.; Niazi, M.B.K.; Chen, G.Z. Electrochemical Production of Sustainable Hydrocarbon Fuels from CO2 Co-electrolysis in Eutectic Molten Melts. ACS Sustain. Chem. Eng. 2020, 8, 12877-12890. [CrossRef]

6. Al-Juboori, O.; Sher, F.; Hazafa, A.; Khan, M.K.; Chen, G.Z. The effect of variable operating parameters for hydrocarbon fuel formation from CO2 by molten salts electrolysis. J. CO2 Util. 2020, 40, 101193. [CrossRef]

7. Sun, Y.; Mang, J.P.; Yang, G.; Li, Z.H. Study on the spectra of spruce lignin with chlorine dioxide oxidation. Spectrosc. Spect. Anal. 2007, 27, 1551-1554.

8. Mallapaty, S. How China Could Be Carbon Neutral by Mid-Century. Nature 2020, 586, 482-483. [CrossRef] [PubMed]

9. YLiu, Y.; Min, J.L.; Feng, X.Y.; He, Y.; Liu, J.Z.; Wang, Y.X.; He, J.; Do, H.N.; Sage, V.; Yang, G.; et al. A Review of Biohydrogen Productions from Lignocellulosic Precursor via Dark Fermentation: Perspective on Hydrolysate Composition and ElectronEquivalent Balance. Energies 2020, 13, 1-27.

10. Sun, Y.; Wang, Y.S.; Yang, G.; Sun, Z. Optimization of biohydrogen production using acid pretreated corn stover hydrolysate followed by nickel nanoparticle addition. Int. J. Energy Res. 2020, 44, 1843-1857. [CrossRef]

11. Sun, Y.; Zhang, J.; Yang, G.; Li, Z. Analysis of trace elements in corn by inductively coupled plasma-atomic emission spectrometry. Food Sci. 2007, 28, 236-237.

12. Al-Shara, N.K.; Sher, F.; Yaqoob, A.; Chen, G.Z. Electrochemical investigation of novel reference electrode $\mathrm{Ni} / \mathrm{Ni}(\mathrm{OH})_{2}$ in comparison with silver and platinum inert quasi-reference electrodes for electrolysis in eutectic molten hydroxide. Int. J. Hydrogen Energy 2019, 44, 27224-27236. [CrossRef]

13. Al-Shara, N.K.; Sher, F.; Iqbal, S.Z.; Sajid, Z.; Chen, G.Z. Electrochemical study of different membrane materials for the fabrication of stable, reproducible and reusable reference electrode. J. Energy Chem. 2020, 49, 33-41. [CrossRef]

14. Sun, Y.; Yang, G.; Zhang, J.P.; Wen, C.; Sun, Z. Optimization and kinetic modeling of an enhanced bio-hydrogen fermentation with the addition of synergistic biochar and nickel nanoparticle. Int. J. Energy Res. 2019, 43, 983-999. [CrossRef]

15. Martínez, I.; Grasa, G.; Meyer, J.; Di Felice, L.; Kazi, S.; Sanz, C.; Maury, D.; Voisin, C. Performance and operating limits of a sorbent-catalyst system for sorption-enhanced reforming (SER) in a fluidized bed reactor. Chem. Eng. Sci. 2019, 205, 94-105. [CrossRef]

16. Di Giuliano, A.; Giancaterino, F.; Courson, C.; Foscolo, P.U.; Gallucci, K. Development of a Ni-CaO-mayenite combined sorbent-catalyst material for multicycle sorption enhanced steam methane reforming. Fuel 2018, 234, 687-699. [CrossRef]

17. Sun, Y.; Zhang, J.P.; Yang, G.; Li, Z.H. An improved process for preparing activated carbon with large specific surface area from corncob. Chem. Biochem. Eng. Q. 2007, 21, 169-174. 
18. Sun, Y.; Yang, G.; Xu, M.; Xu, J.; Sun, Z. A simple coupled ANNs-RSM approach in modeling product distribution of FischerTropsch synthesis using a microchannel reactor with Ru-promoted $\mathrm{Co} / \mathrm{Al}_{2} \mathrm{O}_{3}$ catalyst. Int. J. Energy Res. 2019, 44, $1046-1061$. [CrossRef]

19. Wang, Y.S.; Yang, G.; Sage, V.; Xu, J.; Sun, G.Z.; He, J.; Sun, Y. Optimization of dark fermentation for biohydrogen production using a hybrid artificial neural network (ANN) and response surface methodology (RSM) approach. Environ. Prog. Sustain. Energy 2020. [CrossRef]

20. Sun, Y.; Yang, G.; Wen, C.; Zhang, L.; Sun, Z. Artificial neural networks with response surface methodology for optimization of selective CO2 hydrogenation using K-promoted iron catalyst in a microchannel reactor. J. CO2 Util. 2018, 24, 10-21. [CrossRef]

21. Wang, M.; Tan, X.; Motuzas, J.; Li, J.; Liu, S. Hydrogen production by methane steam reforming using metallic nickel hollow fiber membranes. J. Membr. Sci. 2021, 620, 118909. [CrossRef]

22. Meloni, E.; Martino, M.; Ricca, A.; Palma, V. Ultracompact methane steam reforming reactor based on microwaves susceptible structured catalysts for distributed hydrogen production. Int. J. Hydrogen Energy 2021, 46, 13729-13747. [CrossRef]

23. Zhu, X.; Liu, X.; Lian, H.-Y.; Liu, J.-L.; Li, X.-S. Plasma catalytic steam methane reforming for distributed hydrogen production Catal. Today 2019, 337, 69-75. [CrossRef]

24. Wu, H.-C.; Rui, Z.; Lin, J.Y.S. Hydrogen production with carbon dioxide capture by dual-phase ceramic-carbonate membrane reactor via steam reforming of methane. J. Membr. Sci. 2020, 598, 117780. [CrossRef]

25. Noh, Y.S.; Lee, K.-Y.; Moon, D.J. Hydrogen production by steam reforming of methane over nickel based structured catalysts supported on calcium aluminate modified SiC. Int. J. Hydrogen Energy 2019, 44, 21010-21019. [CrossRef]

26. Xu, F.; Wang, Y.-m.; Li, F.; Nie, X.-y.; Zhu, L.-H. Hydrogen production by the steam reforming and partial oxidation of methane under the dielectric barrierdischarge. J. Fuel Chem. Technol. 2021, 49, 367-373. [CrossRef]

27. Araújo, P.M.; da Costa, K.M.; Passos, F.B. Hydrogen production from methane autothermal reforming over CaTiO3, BaTiO3 and SrTiO3 supported nickel catalysts. Int. J. Hydrogen Energy 2021, 46, 24107-24116. [CrossRef]

28. Lian, H.-Y.; Liu, J.-L.; Li, X.-S.; Zhu, X.; Weber, A.Z.; Zhu, A.-M. Plasma chain catalytic reforming of methanol for on-board hydrogen production. Chem. Eng. J. 2019, 369, 245-252. [CrossRef]

29. Nguyen, T.; Abdin, Z.; Holm, T.; Mérida, W. Grid-connected hydrogen production via large-scale water electrolysis. Energy Convers. Manag. 2019, 200, 112108. [CrossRef]

30. Zhang, C.; Greenblatt, J.B.; Wei, M.; Eichman, J.; Saxena, S.; Muratori, M.; Guerra, O.J. Flexible grid-based electrolysis hydrogen production for fuel cell vehicles reduces costs and greenhouse gas emissions. Appl. Energy 2020, 278, 115651. [CrossRef]

31. Purnami, N.; Hamidi, M.N.; Sasongko, D.; Widhiyanuriyawan, I.N.G. Wardana, Strengthening external magnetic fields with activated carbon graphene for increasing hydrogen production in water electrolysis. Int. J. Hydrogen Energy 2020, 45, 19370-19380. [CrossRef]

32. Avci, A.C.; Toklu, E. A new analysis of two phase flow on hydrogen production from water electrolysis. Int. J. Hydrogen Energy 2021. [CrossRef]

33. Al-Shara, N.K.; Sher, F.; Iqbal, S.Z.; Curnick, O.; Chen, G.Z. Design and optimization of electrochemical cell potential for hydrogen gas production. J. Energy Chem. 2021, 52, 421-427. [CrossRef]

34. Sher, F.; Al-Shara, N.K.; Iqbal, S.Z.; Jahan, Z.; Chen, G.Z. Enhancing hydrogen production from steam electrolysis in molten hydroxides via selection of non-precious metal electrodes. Int. J. Hydrogen Energy 2020, 45, 28260-28271. [CrossRef]

35. Ju, H.; Giddey, S.; Badwal, S.P.S. Role of iron species as mediator in a PEM based carbon-water co-electrolysis for cost-effective hydrogen production. Int. J. Hydrogen Energy 2018, 43, 9144-9152. [CrossRef]

36. Kumar, S.S.; Ramakrishna, S.U.B.; Krishna, S.V.; Srilatha, K.; Devi, B.R.; Himabindu, V. Synthesis of titanium (IV) oxide composite membrane for hydrogen production through alkaline water electrolysis. S. Afr. J. Chem. Eng. 2018, $25,54-61$.

37. Wang, L.; Chen, M.; Küngas, R.; Lin, T.-E.; Diethelm, S.; Maréchal, F.; Van Herle, J. Power-to-fuels via solid-oxide electrolyzer: Operating window and techno-economics. Renew. Sustain. Energy Rev. 2019, 110, 174-187. [CrossRef]

38. Faid, A.Y.; Barnett, A.O.; Seland, F.; Sunde, S. NiCu mixed metal oxide catalyst for alkaline hydrogen evolution in anion exchange membrane water electrolysis. Electrochim. Acta 2021, 371, 137837. [CrossRef]

39. Bhavanari, M.; Lee, K.-R.; Tseng, C.-J.; Tang, I.H.; Chen, H.-H. CuFe electrocatalyst for hydrogen evolution reaction in alkaline electrolysis. Int. J. Hydrogen Energy 2021. [CrossRef]

40. Gutiérrez-Martín, F.; Amodio, L.; Pagano, M. Hydrogen production by water electrolysis and off-grid solar PV. Int. J. Hydrogen Energy 2020. [CrossRef]

41. Kakoulaki, G.; Kougias, I.; Taylor, N.; Dolci, F.; Moya, J.; Jäger-Waldau, A. Green hydrogen in Europe-A regional assessment: Substituting existing production with electrolysis powered by renewables. Energy Convers. Manag. 2020, 228, 113649. [CrossRef]

42. Holm, T.; Borsboom-Hanson, T.; Herrera, O.E.; Mérida, W. Hydrogen costs from water electrolysis at high temperature and pressure. Energy Convers. Manag. 2021, 237, 114106. [CrossRef]

43. Aydin, E.S.; Yucel, O.; Sadikoglu, H. Experimental study on hydrogen-rich syngas production via gasification of pine cone particles and wood pellets in a fixed bed downdraft gasifier. Int. J. Hydrogen Energy 2019, 44, 17389-17396. [CrossRef]

44. Chianese, S.; Fail, S.; Binder, M.; Rauch, R.; Hofbauer, H.; Molino, A.; Blasi, A.; Musmarra, D. Experimental investigations of hydrogen production from CO catalytic conversion of tar rich syngas by biomass gasification. Catal. Today 2016, 277, 182-191. [CrossRef] 
45. Jahromi, R.; Rezaei, M.; Samadi, S.H.; Jahromi, H. Biomass gasification in a downdraft fixed-bed gasifier: Optimization of operating conditions. Chem. Eng. Sci. 2021, 231, 116249. [CrossRef]

46. Peng, W.-X.; Ge, S.-B.; Ebadi, A.G.; Hisoriev, H.; Esfahani, M.J. Syngas production by catalytic co-gasification of coal-biomass blends in a circulating fluidized bed gasifier. J. Clean. Prod. 2017, 168, 1513-1517. [CrossRef]

47. Xiao, Y.; Xu, S.; Song, Y.; Shan, Y.; Wang, C.; Wang, G. Biomass steam gasification for hydrogen-rich gas production in a decoupled dual loop gasification system. Fuel Process. Technol. 2017, 165, 54-61. [CrossRef]

48. Anniwaer, A.; Chaihad, N.; Zhang, M.; Wang, C.; Yu, T.; Kasai, Y.; Abudula, A.; Guan, G. Hydrogen-rich gas production from steam co-gasification of banana peel with agricultural residues and woody biomass. Waste Manag. 2021, 125, 204-214. [CrossRef]

49. Li, C.; Liu, R.; Zheng, J.; Wang, Z.; Zhang, Y. Production of hydrogen-rich syngas from absorption-enhanced steam gasification of biomass with conch shell-based absorbents. Int. J. Hydrogen Energy 2021. [CrossRef]

50. Posso, F.; Siguencia, J.; Narváez, R. Residual biomass-based hydrogen production: Potential and possible uses in Ecuador. Int. J. Hydrogen Energy 2020, 45, 13717-13725. [CrossRef]

51. Li, S.; Zheng, H.; Zheng, Y.; Tian, J.; Jing, T.; Chang, J.-S.; Ho, S.-H. Recent advances in hydrogen production by thermo-catalytic conversion of biomass. Int. J. Hydrogen Energy 2019, 44, 14266-14278. [CrossRef]

52. Yang, S.; Chen, L.; Sun, L.; Xie, X.; Zhao, B.; Si, H.; Zhang, X.; Hua, D. Novel Ni-Al nanosheet catalyst with homogeneously embedded nickel nanoparticles for hydrogen-rich syngas production from biomass pyrolysis. Int. J. Hydrogen Energy 2021, 46, 1762-1776. [CrossRef]

53. Tomasek, S.; Lónyi, F.; Valyon, J.; Hancsók, J. Fuel purpose hydrocracking of biomass based Fischer-Tropsch paraffin mixtures on bifunctional catalysts. Energy Convers. Manag. 2020, 213, 112775. [CrossRef]

54. Sun, Y.; Wang, Y.X.; He, J.; Yusuf, A.; Wang, Y.X.; Yang, G.; Xiao, X. Comprehensive kinetic model for acetylene pretreated mesoporous silica supported bimetallic Co-Ni catalyst during Fischer-Tropsch synthesis. Chem. Eng. Sci. 2021. [CrossRef]

55. Sun, Y.; Jia, Z.; Yang, G.; Zhang, L.; Sun, Z. Fischer-Tropsch synthesis using iron based catalyst in a microchannel reactor: Performance evaluation and kinetic modeling. Int. J. Hydrogen Energy 2017, 42, 29222-29235. [CrossRef]

56. Sun, Y.; Yang, G.; Zhang, L.; Sun, Z. Fischer-Tropsch synthesis in a microchannel reactor using mesoporous silica supported bimetallic Co-Ni catalyst: Process optimization and kinetic modeling. Chem. Eng. Process. 2017, 119, 44-61. [CrossRef]

57. Batista, A.P.; Gouveia, L.; Marques, P.A.S.S. Fermentative hydrogen production from microalgal biomass by a single strain of bacterium Enterobacter aerogenes-Effect of operational conditions and fermentation kinetics. Renew. Energy 2018, 119, 203-209. [CrossRef]

58. Sugiarto, Y.; Sunyoto, N.M.S.; Zhu, M.; Jones, I.; Zhang, D. Effect of biochar in enhancing hydrogen production by mesophilic anaerobic digestion of food wastes: The role of minerals. Int. J. Hydrogen Energy 2021, 46, 3695-3703. [CrossRef]

59. Khan, I. Waste to biogas through anaerobic digestion: Hydrogen production potential in the developing world-A case of Bangladesh. Int. J. Hydrogen Energy 2020, 45, 15951-15962. [CrossRef]

60. Yang, C.; Wang, C.; Zhou, L.; Duan, W.; Song, Y.; Zhang, F.; Zhen, Y.; Zhang, J.; Bao, W.; Lu, Y.; et al. Refining d-band center in Ni0.85Se by Mo doping: A strategy for boosting hydrogen generation via coupling electrocatalytic oxidation 5hydroxymethylfurfural. Chem. Eng. J. 2021, 422, 130125. [CrossRef]

61. Situmorang, Y.A.; Zhao, Z.; An, P.; Yu, T.; Rizkiana, J.; Abudula, A.; Guan, G. A novel system of biomass-based hydrogen production by combining steam bio-oil reforming and chemical looping process. Appl. Energy 2020, 268, 115122. [CrossRef]

62. Moneti, M.; Di Carlo, A.; Bocci, E.; Foscolo, P.U.; Villarini, M.; Carlini, M. Influence of the main gasifier parameters on a real system for hydrogen production from biomass. Int. J. Hydrogen Energy 2016, 41, 11965-11973. [CrossRef]

63. Dhanavath, K.N.; Shah, K.; Islam, M.S.; Ronte, A.; Parthasarathy, R.; Bhargava, S.K.; Bankupalli, S. Experimental investigations on entrained flow gasification of Torrefied Karanja Press Seed Cake. J. Environ. Chem. Eng. 2018, 6, 1242-1249. [CrossRef]

64. Schneider, J.; Grube, C.; Herrmann, A.; Rönsch, S. Atmospheric entrained-flow gasification of biomass and lignite for decentralized applications. Fuel Process. Technol. 2016, 152, 72-82. [CrossRef]

65. Yao, X.; Zhao, Z.; Chen, S.; Zhou, H.; Xu, K. Migration and transformation behaviours of ash residues from a typical fixed-bed gasification station for biomass syngas production in China. Energy 2020, 201, 117646. [CrossRef]

66. Marcantonio, V.; De Falco, M.; Capocelli, M.; Bocci, E.; Colantoni, A.; Villarini, M. Process analysis of hydrogen production from biomass gasification in fluidized bed reactor with different separation systems. Int. J. Hydrogen Energy 2019, 44, 10350-10360. [CrossRef]

67. Chen, Y.-H.; Ngo, T.N.L.T.; Chiang, K.-Y. Enhanced hydrogen production in co-gasification of sewage sludge and industrial wastewater sludge by a pilot-scale fluidized bed gasifier. Int. J. Hydrogen Energy 2021, 46, 14083-14095. [CrossRef]

68. Butera, G.; Gadsbøll, R.Ø.; Ravenni, G.; Ahrenfeldt, J.; Henriksen, U.B.; Clausen, L.R. Thermodynamic analysis of methanol synthesis combining straw gasification and electrolysis via the low temperature circulating fluid bed gasifier and a char bed gas cleaning unit. Energy 2020, 199, 117405. [CrossRef]

69. Cao, Y.; Fu, L.; Mofrad, A. Combined-gasification of biomass and municipal solid waste in a fluidized bed gasifier. J. Energy Inst. 2019, 92, 1683-1688. [CrossRef]

70. Nam, H.; Wang, S.; Sanjeev, K.C.; Seo, M.W.; Adhikari, S.; Shakya, R.; Lee, D.; Shanmugam, S.R. Enriched hydrogen production over air and air-steam fluidized bed gasification in a bubbling fluidized bed reactor with CaO: Effects of biomass and bed material catalyst. Energy Convers. Manag. 2020, 225, 113408. [CrossRef] 
71. González-Vázquez, M.P.; García, R.; Gil, M.V.; Pevida, C.; Rubiera, F. Comparison of the gasification performance of multiple biomass types in a bubbling fluidized bed. Energy Convers. Manag. 2018, 176, 309-323. [CrossRef]

72. Yaghoubi, E.; Xiong, Q.; Doranehgard, M.H.; Yeganeh, M.M.; Shahriari, G.; Bidabadi, M. The effect of different operational parameters on hydrogen rich syngas production from biomass gasification in a dual fluidized bed gasifier. Chem. Eng. ProcessingProcess Intensif. 2018, 126, 210-221. [CrossRef]

73. Jeong, Y.-S.; Choi, Y.-K.; Kang, B.-S.; Ryu, J.-H.; Kim, H.-S.; Kang, M.-S.; Ryu, L.-H.; Kim, J.-S. Lab-scale and pilot-scale two-stage gasification of biomass using active carbon for production of hydrogen-rich and low-tar producer gas. Fuel Process. Technol. 2020, 198, 106240. [CrossRef]

74. Hanchate, N.; Malhotra, R.; Mathpati, C.S. Design of experiments and analysis of dual fluidized bed gasifier for syngas production: Cold flow studies. Int. J. Hydrogen Energy 2021, 46, 4776-4787. [CrossRef]

75. Kulkarni, A.; Baker, R.; Abdoulmomine, N.; Adhikari, S.; Bhavnani, S. Experimental study of torrefied pine as a gasification fuel using a bubbling fluidized bed gasifier. Renew. Energy 2016, 93, 460-468. [CrossRef]

76. Valin, S.; Bedel, L.; Guillaudeau, J.; Thiery, S.; Ravel, S. CO2 as a substitute of steam or inert transport gas in a fluidised bed for biomass gasification. Fuel 2016, 177, 288-295. [CrossRef]

77. Kook, J.W.; Choi, H.M.; Kim, B.H.; Ra, H.W.; Yoon, S.J.; Mun, T.Y.; Kim, J.H.; Kim, Y.K.; Lee, J.G.; Seo, M.W. Gasification and tar removal characteristics of rice husk in a bubbling fluidized bed reactor. Fuel 2016, 181, 942-950. [CrossRef]

78. Bharath, M.; Raghavan, V.; Prasad, B.V.S.S.S.; Chakravarthy, S.R. Co-gasification of Indian rice husk and Indian coal with high-ash in bubbling fluidized bed gasification reactor. Appl. Therm. Eng. 2018, 137, 608-615. [CrossRef]

79. Мa, X.; Zhao, X.; Gu, J.; Shi, J. Co-gasification of coal and biomass blends using dolomite and olivine as catalysts. Renew. Energy 2019, 132, 509-514. [CrossRef]

80. Mallick, D.; Mahanta, P.; Moholkar, V.S. Co-gasification of coal/biomass blends in $50 \mathrm{kWe}$ circulating fluidized bed gasifier. J. Energy Inst. 2020, 93, 99-111. [CrossRef]

81. Nakyai, T.; Authayanun, S.; Patcharavorachot, Y.; Arpornwichanop, A.; Assabumrungrat, S.; Saebea, D. Exergoeconomics of hydrogen production from biomass air-steam gasification with methane co-feeding. Energy Convers. Manag. 2017, 140, 228-239. [CrossRef]

82. Wan, Z.; Hu, J.; Qi, X. Numerical analysis of hydrodynamics and thermochemical property of biomass gasification in a pilot-scale circulating fluidized bed. Energy 2021, 225, 120254. [CrossRef]

83. Di Marcello, M.; Tsalidis, G.A.; Spinelli, G.; de Jong, W.; Kiel, J.H.A. Pilot scale steam-oxygen CFB gasification of commercial torrefied wood pellets. The effect of torrefaction on the gasification performance. Biomass Bioenergy 2017, 105, 411-420. [CrossRef]

84. Cao, Y.; Bai, Y.; Du, J. Air-steam gasification of biomass based on a multi-composition multi-step kinetic model: A clean strategy for hydrogen-enriched syngas production. Sci. Total Environ. 2021, 753, 141690. [CrossRef]

85. Liu, Z.-S.; Lin, C.-L.; Chang, T.-J.; Weng, W.-C. Waste-gasification efficiency of a two-stage fluidized-bed gasification system. Waste Manag. 2016, 48, 250-256. [CrossRef]

86. Liu, L.; Huang, Y.; Cao, J.; Liu, C.; Dong, L.; Xu, L.; Zha, J. Experimental study of biomass gasification with oxygen-enriched air in fluidized bed gasifier. Sci. Total. Environ. 2018, 626, 423-433. [CrossRef]

87. Lin, C.-L.; Wu, M.-H.; Weng, W.-C. Effect of the type of bed material in two-stage fluidized bed gasification reactors on hydrogen gas synthesis and heavy metal distribution. Int. J. Hydrogen Energy 2019, 44, 5633-5639. [CrossRef]

88. Kuo, J.-H.; Lin, C.-L.; Ho, C.-Y. Effect of fluidization/gasification parameters on hydrogen generation in syngas during fluidizedbed gasification process. Int. J. Hydrogen Energy 2021. [CrossRef]

89. Wang, G.; Xu, S.; Wang, C.; Zhang, J. Biomass Gasification and Hot Gas Upgrading in a Decoupled Dual-Loop Gasifier. Energy Fuels 2017, 31, 8181-8192. [CrossRef]

90. Robinson, T.; Bronson, B.; Gogolek, P.; Mehrani, P. Comparison of the air-blown bubbling fluidized bed gasification of wood and wood-PET pellets. Fuel 2016, 178, 263-271. [CrossRef]

91. Manatura, K.; Lu, J.-H.; Wu, K.-T.; Hsu, H.-T. Exergy analysis on torrefied rice husk pellet in fluidized bed gasification. Appl. Therm. Eng. 2017, 111, 1016-1024. [CrossRef]

92. Couto, N.; Silva, V.; Cardoso, J.; Rouboa, A. 2nd law analysis of Portuguese municipal solid waste gasification using CO2/air mixtures. J. CO2 Util. 2017, 20, 347-356. [CrossRef]

93. Zhang, J.; Wang, M.; Xu, S.; Feng, Y. Hydrogen and methane mixture from biomass gasification coupled with catalytic tar reforming, methanation and adsorption enhanced reforming. Fuel Process. Technol. 2019, 192, 147-153. [CrossRef]

94. Hervy, M.; Remy, D.; Dufour, A.; Mauviel, G. Air-blown gasification of Solid Recovered Fuels (SRFs) in lab-scale bubbling fluidized-bed: Influence of the operating conditions and of the SRF composition. Energy Convers. Manag. 2019, 181, 584-592. [CrossRef]

95. Nguyen, N.M.; Alobaid, F.; May, J.; Peters, J.; Epple, B. Experimental study on steam gasification of torrefied woodchips in a bubbling fluidized bed reactor. Energy 2020, 202, 117744. [CrossRef]

96. Pio, D.T.; Tarelho, L.A.C.; Tavares, A.M.A.; Matos, M.A.A.; Silva, V. Co-gasification of refused derived fuel and biomass in a pilot-scale bubbling fluidized bed reactor. Energy Convers. Manag. 2020, 206, 112476. [CrossRef]

97. Gupta, S.; Choudhary, S.; Kumar, S.; De, S. Large eddy simulation of biomass gasification in a bubbling fluidized bed based on the multiphase particle-in-cell method. Renew. Energy 2021, 163, 1455-1466. [CrossRef] 
98. Kartal, F.; Özveren, U. A comparative study for biomass gasification in bubbling bed gasifier using Aspen HYSYS. Bioresour. Technol. Rep. 2021, 13, 100615. [CrossRef]

99. Porcu, A.; Xu, Y.; Mureddu, M.; Dessì, F.; Shahnam, M.; Rogers, W.A.; Sastri, B.S.; Pettinau, A. Experimental validation of a multiphase flow model of a lab-scale fluidized-bed gasification unit. Appl. Energy 2021, 293, 116933. [CrossRef]

100. Nguyen, N.M.; Alobaid, F.; Epple, B. Chemical looping gasification of torrefied woodchips in a bubbling fluidized bed test rig using iron-based oxygen carriers. Renew. Energy 2021, 172, 34-45. [CrossRef]

101. Pandey, D.S.; Kwapinska, M.; Gómez-Barea, A.; Horvat, A.; Fryda, L.E.; Rabou, L.P.L.M.; Leahy, J.J.; Kwapinski, W. Poultry Litter Gasification in a Fluidized Bed Reactor: Effects of Gasifying Agent and Limestone Addition. Energy Fuels 2016, 30, 3085-3096. [CrossRef]

102. Agu, C.E.; Moldestad, B.M.E.; Pfeifer, C. Assessment of Combustion and Gasification Behavior in a Bubbling Fluidized Bed Reactor: A Comparison between Biomass with and without Chemical Additives. Energy Fuels 2020, 34, 9654-9663. [CrossRef]

103. Kang, P.; Hu, X.E.; Lu, Y.; Wang, K.; Zhang, R.; Han, L.; Yuan, H.; Chen, H.; Luo, X.; Zhou, Y.J. Modeling and Optimization for Gas Distribution Patterns on Biomass Gasification Performance of a Bubbling Spout Fluidized Bed. Energy Fuels 2020, 34, 1750-1763. [CrossRef]

104. Lardier, G.; Kaknics, J.; Dufour, A.; Michel, R.; Cluet, B.; Authier, O.; Poirier, J.; Mauviel, G. Gas and Bed Axial Composition in a Bubbling Fluidized Bed Gasifier: Results with Miscanthus and Olivine. Energy Fuels 2016, 30, 8316-8326. [CrossRef]

105. Niu, M.; Huang, Y.; Jin, B.; Liang, S.; Dong, Q.; Gu, H.; Sun, R. A novel two-stage enriched air biomass gasification for producing low-tar high heating value fuel gas: Pilot verification and performance analysis. Energy 2019, 173, 511-522. [CrossRef]

106. Lin, C.-L.; Chou, J.-D.; Iu, C.-H. Effects of second-stage bed materials on hydrogen production in the syngas of a two-stage gasification process. Renew. Energy 2020, 154, 903-912. [CrossRef]

107. Zhu, H.L.; Zhang, Y.S.; Materazzi, M.; Aranda, G.; Brett, D.J.L.; Shearing, P.R.; Manos, G. Co-gasification of beech-wood and polyethylene in a fluidized-bed reactor. Fuel Process. Technol. 2019, 190, 29-37. [CrossRef]

108. Valdés, C.F.; Chejne, F.; Marrugo, G.; Macias, R.J.; Gómez, C.A.; Montoya, J.I.; Londoño, C.A.; De la Cruz, J.; Arenas, E. Cogasification of sub-bituminous coal with palm kernel shell in fluidized bed coupled to a ceramic industry process. Appl. Therm. Eng. 2016, 107, 1201-1209. [CrossRef]

109. Couto, N.; Monteiro, E.; Silva, V.; Rouboa, A. Hydrogen-rich gas from gasification of Portuguese municipal solid wastes. Int. J. Hydrogen Energy 2016, 41, 10619-10630. [CrossRef]

110. Kaushal, P.; Tyagi, R. Advanced simulation of biomass gasification in a fluidized bed reactor using ASPEN PLUS. Renew. Energy 2017, 101, 629-636. [CrossRef]

111. Prestipino, M.; Chiodo, V.; Maisano, S.; Zafarana, G.; Urbani, F.; Galvagno, A. Hydrogen rich syngas production by air-steam gasification of citrus peel residues from citrus juice manufacturing: Experimental and simulation activities. Int. J. Hydrogen Energy 2017, 42, 26816-26827. [CrossRef]

112. Peng, W.X.; Wang, L.S.; Mirzaee, M.; Ahmadi, H.; Esfahani, M.J.; Fremaux, S. Hydrogen and syngas production by catalytic biomass gasification. Energy Convers. Manag. 2017, 135, 270-273. [CrossRef]

113. Liu, C.; Huang, Y.; Niu, M.; Pei, H.; Liu, L.; Wang, Y.; Dong, L.; Xu, L. Influences of equivalence ratio, oxygen concentration and fluidization velocity on the characteristics of oxygen-enriched gasification products from biomass in a pilot-scale fluidized bed. Int. J. Hydrogen Energy 2018, 43, 14214-14225. [CrossRef]

114. Savuto, E.; Di Carlo, A.; Steele, A.; Heidenreich, S.; Gallucci, K.; Rapagnà, S. Syngas conditioning by ceramic filter candles filled with catalyst pellets and placed inside the freeboard of a fluidized bed steam gasifier. Fuel Process. Technol. 2019, 191, 44-53. [CrossRef]

115. Jin, K.; Ji, D.; Xie, Q.; Nie, Y.; Yu, F.; Ji, J. Hydrogen production from steam gasification of tableted biomass in molten eutectic carbonates. Int. J. Hydrogen Energy 2019, 44, 22919-22925. [CrossRef]

116. Ismail, T.M.; Ramos, A.; Monteiro, E.; El-Salam, M.A.; Rouboa, A. Parametric studies in the gasification agent and fluidization velocity during oxygen-enriched gasification of biomass in a pilot-scale fluidized bed: Experimental and numerical assessment. Renew. Energy 2020, 147, 2429-2439. [CrossRef]

117. Mallick, D.; Mahanta, P.; Moholkar, V.S. Co-gasification of biomass blends: Performance evaluation in circulating fluidized bed gasifier. Energy 2020, 192, 116682. [CrossRef]

118. Inayat, A.; Khan, Z.; Aslam, M.; Shahbaz, M.; Ahmad, M.M.; Mutalib, M.I.A.; Yusup, S. Integrated adsorption steam gasification for enhanced hydrogen production from palm waste at bench scale plant. Int. J. Hydrogen Energy 2020. [CrossRef]

119. Kibret, H.A.; Kuo, Y.-L.; Ke, T.-Y.; Tseng, Y.-H. Gasification of spent coffee grounds in a semi-fluidized bed reactor using steam and CO2 gasification medium. J. Taiwan Inst. Chem. Eng. 2021, 119, 115-127. [CrossRef]

120. Shahbaz, M.; Yusup, S.; Inayat, A.; Patrick, D.O.; Ammar, M.; Pratama, A. Cleaner Production of Hydrogen and Syngas from Catalytic Steam Palm Kernel Shell Gasification Using CaO Sorbent and Coal Bottom Ash as a Catalyst. Energy Fuels 2017, 31, 13824-13833. [CrossRef]

121. Tian, Y.; Zhou, X.; Lin, S.; Ji, X.; Bai, J.; Xu, M. Syngas production from air-steam gasification of biomass with natural catalysts. Sci. Total Environ. 2018, 645, 518-523. [CrossRef] [PubMed]

122. Kumar, A.; Guangul, F.M.; Inayat, M.; Sulaiman, S. Effect of fuel particle size and blending ratio on syngas production and performance of co-gasification. J. Mech. Eng. Sci. 2016, 10, 2188. 
123. Madadian, E.; Orsat, V.; Lefsrud, M. Comparative Study of Temperature Impact on Air Gasification of Various Types of Biomass in a Research-Scale Down-draft Reactor. Energy Fuels 2017, 31, 4045-4053. [CrossRef]

124. Abdoulmoumine, N.; Kulkarni, A.; Adhikari, S. Effects of temperature and equivalence ratio on mass balance and energy analysis in loblolly pine oxygen gasification. Energy Sci. Eng. 2016, 4, 256-268. [CrossRef] 